Öz

Kentleşme ve sermayeye dayalı kentse politikalardan dolayı niceliksel olarak azalan kamusal mekânlar ayrıca niteliklerini de kaybederek kavşak noktasına dönüşmüşlerdir. Değişen kamusal alanlara karșılık oluşan alternatif açık alanlar, mekânsal açıdan yeni sınırlar çizebilen ve kullanıcılarına farklı deneyimler sunabilen arayüzler olarak tanımlanabilmektedir. Oluşumlarının kentsel politikaların temel özellikleri olan kullanıcı odaklı, kamu yararına yönelik ve katılımla yürütülmesi hedeflenmektedir. Kentsel politika; "ortak amaçlar ve sorunlar karşısında, kentsel yaşamın sağlıklı bir şekilde devamını sağlamaya yönelik hedefler, stratejiler oluşturulması ve kamu müdahaleleri arasında uyumun sağlanması için merkezi otoritenin getireceği vasıtalar bütünü” olarak tanımlanmaktadır. Bu bağlamda müzeler alternatif açık alan potansiyeline sahip mekânlardan biri olarak

değerlendirilebilmektedir. Müzelerin mülkiyet sınırlarında veya yakın çevrelerinde bulunan açık alanların kentsel mekân örüntüsüyle bütünleşmiş biçimde ele alınarak tasarlanması, kentsel yaşam üzerinde pozitif etkilere sahip olmaktadır Calıssmada İstanbul'da Tarihi Yarımada, Haliç kıyı bölgesi, Galata-Pera bölgesi ve Şişli-Beşiktaş ilçelerinde tarihi veya modern nitelikte bulunan müzelerin bina çevresiyle yakın bölgelerinde yer alan açık alanların, alternatif açık alan kapsamında değerlendirilmesiyle kentsel yaşam üzerindeki etkilerinin incelenmesi ve alternatif açık alan olușturmaya yönelik müzelerde kullanıșlılık kriterlerinin belirlenmesi amaçlanmıștır. Calıșma sonucunda alternatif açık alan olusturma kamu politikası kapsamında müzelerde gerekli kriterler oluşturulmuş ve politikanın kente etkileri incelenmiștir.

\section{Abstract}

The public spaces that decreased quantitatively due to urbanization and capital-based urban policies also lost their qualities. Alternative open spaces formed in response to changing public spaces can be defined as interfaces that can draw new boundaries in terms of spatial and offer different experiences to its users. Alternative open spaces are aimed to be implemented in a user-oriented, public benefit and participation which are the basic features of urban policy. Urban policy is defined as

"the set of means to be brought by the central authority in order to establish goals and strategies to ensure the healthy continuation of urban life in the face of common goals and problems, and to ensure harmony among public interventions". In this context, museums can be considered as one of the places with alternative open space potential. Designing open spaces in the property boundaries of museums or close surroundings in an integrated manner with the urban has positive effects on urban life. In this study, historical or modern museums of the Historical Peninsula, the Golden Hor coastal area, Galata-Pera region, Şişli and Besiktas districts are evaluated within the

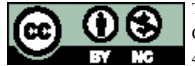

This work is licensed under a Creative Commons Attribution-NonCommercid 4.0 International License.

\title{
Müze Bahçelerinin Alternatif Açık Alan Olarak Kullanilmasinin Kentsel Yaşam Üzerindeki Etkileri: istanbul Örneği
}

D Damla Erenler Ístanbul Teknik Üniversitesi Mimarlık Fakültesi, Kentsel Tasarım Lisansüstü Programı

(1) Eren Kürkçüoğlu Ístanbul Teknik Üniversitesi Mimarlık Fakültesi, Şehir ve Bölge Planlama Bölümü

Başvuru tarihi/Received: 21.08.2020, Kabul tarihi/Final Acceptance: 16.10 .2020

\section{Giris}

Kentsel kimlik elemanlarından biri olan ve kentsel yaşama ev sahipliği yapan kentsel açık alanlar, karşılaşmalara ve kentlinin sosyo-kültürel ihtiyaçlarına cevap veren kolektif üretim merkezleridir. Gehl (1996) binalar arasında oluşan kentsel yaşamın, mimarlı̆̆ın ve planlamanın daha dikkatli davranmayı hak eden bir boyutu olduğunu vurgular. Binalar arasındaki yaşam, kamusal mekânlardaki insan faaliyetlerini içerir. Kentsel açık alanlar sosyal etkileşim ve alg1, kentsel rekreasyon ve şehir yaşamının duyusal deneyiminin gerçekleştiği yaşamsal alanlardır. Planlama süreçleri binalar arasındaki boşlukları anlayarak başlamalıdır.

Modernizm ve postmodernizm süreçlerinde üretim ve teknolojide yaşanan gelişmeler ve küreselleşmenin yeryüzündeki fiziksel sınırları kaldırmasıyla ülkeler sermayeyi kendilerine çekmek için rekabete girmişlerdir. Alışılmış mekân ve zaman sınırlarının yok olması, ulaşım faaliyetlerinin gelişmesi ve genişleyen üretim alanlarına paralel olarak artan göçlerle birlikte kentleşme hızlanmıştır. Kent içerisindeki erişimde ağırlık kazanan ulaşım araçlarıyla kamusal mekânlar kullanılmayan boşluklara ve içerisinde günlük hayatın sergilendiği mekânlar yerine geçilip gidilen alanlardan birine dönüşmüştür. Küreselleşmenin tüketim alışkanlıklarımızı değiştirmesiyle kitlesel tüketim mekânları kentlinin yeni kamusal mekânlarını oluşturmaktadır. Sermayeye dayalı kentsel politikalar ve artan nüfusun getirdiği yapılaşma baskısından dolayı kamusal mekânlar niceliksel olarak azalmakta ve niteliksel olarak bir dönüșüm geçirmektedir. $\mathrm{Bu}$ süreç sonucunda tanımlanamayan kentsel boşluklara dönüșen kamusal mekânlar birer geçiş noktası olarak meydanlar, sokaklar, parklar ve tanımlanmamış açık yeşil alanlarla niceliksel olarak sinırlı kullanım seçenekleri sunar hale gelmiştir.

Kamusal alanlarda yaşanan dönüșüm öncelikle kentsel yaşamın niteliğini etkilemektedir. Kentlerin en önemli kolektif ögeleri olan kamusal alanların azalması ve dönüşmesi kentlilerin birbirleriyle ve kentle olan ilișkisini olumsuz yönde etkilemektedir. Kentsel iletişimin zayıfladığı kentlerde insanların başkalarını görme, duyma, başkalarıyla konuşma, etkileşim ve iletişim içerisinde bulunmaları azalmaktadır. Bu durumda kentliler bireyselleșmekte ve toplumun birlikteliği, kolektif üretim ve kentsel yaşam zarar görmektedir. Günümüz kentlerinde de yapılı alan ve kentsel açık alanlar arasındaki ilişkinin bozulmasıyla alternatif açık alan arayışı başlamıştır. Kentliler uyarlanabilir kullanım/tasarım (adaptive use) ve yer oluşturma (placemaking) gibi uygulamalarla yeni kamusal mekânlar üretmektedir. Çatı bahçeleri, uyarlanabilir 
scope of alternative open spaces, and to examine the effects on urban life. It was aimed to determine the usefulness criteria in museums to create alternative open space. As a result of the study, necessary criteria were obtained in museums within the scope of the public policy of creating alternative open spaces and the effects of the policy on the city were examined.

Anahtar Kelimeler: Kamusal alan, alternatif açık alanlar, kentsel yaşam, müze bahçeleri, İstanbul.

Keywords: Public space, alternative open spaces, urban life, museum gardens, Istanbul. kullanım/tasarım (adaptive use) uygulamalarıyla düzenlenen üst geçitler, yeniden tasarlanan çıkmaz sokaklar ve yapı adası ortaları/iç avlular kentlilerinin kentsel ihtiyaçlarına çözüm veren alternatif açık alan uygulamalarındandır. Alternatif açık alan arayışı dünyanın çeşitli kentlerinde yer alan müze bahçelerinde de rastlanılan bir uygulamadır. Müzelerin mülkiyet sınırları içerisindeki ve yakın çevresindeki açık alanlar kentlilerin alternatif açık alanlarını oluşturmaktadır. Yapılaşma baskısı ile kentlerde nicel olarak azalan kentsel açık alanlara karşılık müzelerin sahip oldukları alternatif açık alanlar kentliler için yeni kamusal mekânlar sunmaktadır. Kentlilerin kamusal mekân ihtiyaçlarının karşılanmasında müzelerin açık alanları yapılaşma baskısının yok ettiği açık alanlar yanında yüksek potansiyele sahip alanlara dönüşmektedir. Bu çalışmada da İstanbul'da azalan kentsel açık alan ihtiyacına bir çözüm yolu olarak müze bahçelerinin alternatif açık alan olarak kullanılmasının kentsel yaşama olan etkilerini incelemek çalışmanın gerekliliği düşüncesini ortaya çıkarmıştır.

\section{1. Çalışmanın Amacı}

Bu çalışmada, müzelerin mülkiyet alanı içerisinde ve yakın çevresinde bulunan açık alanların mekânsal ve fiziksel özellikleriyle kent arasındaki ilişki incelenerek, kentlilerin bu mekanları nasıl kullandığı/kullanabileceği sorusu üzerinden alternatif açık alan oluşturmaya yönelik kamusal politika sürecinin oluşturulması amaçlanmaktadır. Bu doğrultuda, kentsel açık alan ihtiyacını karşılamaya yönelik bir kamusal politika aracı olarak müzelerin açık alanlarının alternatif kamusal alanlar olarak değerlendirilmesi çalıșmanın temel amacıdır.

\section{2. Çalışmanın Yöntemi}

Bu çalışmada İstanbul'da farklı alt bölgelerde yer alan müzelerin bina çevresi ve yakın bölgelerinde yer alan açık alanların, alternatif açık alan kapsamında değerlendirilmesi ile kentsel yaşam üzerindeki etkileri incelenecek ve alternatif açık alan kriterleri belirlenecektir. Bu kapsamda;

Konuyla ilgili kitaplar, süreli yayınlar ve akademik makalelerden yararlanılarak bugüne kadar yapılmış çalışmalardan alterna- tif açık alanların kentsel yaşam üzerindeki etkilerine dair genel değerlendirme yapılmış ve çalışmanın teorik temelleri oluşturulmaya çalışılmıştır. Çalışma birbiriyle paralel olarak yürütülen analiz ve değerlendirme çalışmalarına dayanmaktadır. Bunlar;

1) Yöntem Analizi: Alternatif kamusal mekân kullanımına sahip dünyanın çeşitli kentlerinde yer alan müze örnekleri incelenmiştir. Bu örneklerin incelenmesiyle birlikte müzelerin alternatif açık alanlar olarak kullanılmasını sağlayan ve görülme sıklığı yüksek olan nitelikleri öncelikle fiziksel, sosyal ve çevresel olarak gruplanmıştır. Bu gruplama alternatif mekân kullanımı ve mekânlar kapsamında ortak özellikleri bulunan 11 müze ile oluşturulmuştur. Açık alana sahip müzelerin alternatif kamusal mekânlar olarak hizmet vermesini sağlayacak fiziksel çevre, sosyal çevre ve çevresel alg1 alanındaki kriterler elde edilmiştir. Fiziksel çevre kriterleri müzelerin alternatif açık alanlarının yapılı çevreleriyle ilgili özellikleri içerirken sosyal çevre kriterleri alternatif kamusal mekânlardaki kullanım ve kullanıcı niteliklerini kapsamaktadır. Müzelerin açık alanlarının çevresel kalite ve algı ile ilişkili olarak sahip oldukları niteliklerde çevresel algı altında gruplanmıştır.

2) Mevcut Durum Analizi: Bu bölümde çalışma alanı içerisindeki mevcut kentsel açık alanlar tespit edilmiştir. Tespit edilen açık alanların 500 metrelik yürüme mesafesindeki etki alanları analizi çıkarılmış ve çalışma alanı içerisindeki dağılımları elde edilmiştir. Etki alanında dezavantaja sahip bölgeler alt çalışma bölgeleri seçilmiş ve kentsel açık alanları planlama standart ölçütlerine göre irdelenmiştir.

3) Alan Çalışması: Alt bölgedeki açık alanları geçici süreliğine kullanan kullanıcılar ile bir anket çalışması yapılmış ve açık alan ihtiyaçları ile müze bahçelerinin alternatif açık alan oluşturma potansiyeli üzerine çıkarımlar yapılmıştır.

\section{Kavramsal Çerçeve}

\subsection{Kentsel Açık Alan Kavramı ve Dönüsümü}

Kentsel açık alanlar modern toplum kuramlarında, kamunun kullanımına açık ve 
kamu yararına yönelik düşünce ve eylemlerin üretildiği ortak toplumsal etkinlik alanlarıdır. Kolektif üretimin merkezi ve kentsel kimlik ögesi olan kamusal alanlar, kentlinin kendisinin ve diğerlerinin farkındalığını ve sosyal ilişkiler kurmasını sağlayan açık alanlardır. Habermas'a (2004) göre kamusal alan, toplumda sınıfsal ayrım gözetilmeden ve baskı altında tutulmadan kamu yararına ilişkin toplumsal konuların çeşitli eylemlerle oluşturulmasıdır. Meydan, park, rekreasyon alanları ve sokaklardan oluşan kamusal alanlar, toplumun iktidara tepkisini gösterebildiği, şikayet ve taleplerini dile getirdiği ve kentlilerin kamu yararı gözetilen meseleler hakkında bir kisitlama olmadan bir arada olma, görüşlerini yansıtabilme gibi kamusal davranışlar sergilediği alanlardır (Habermas, 2000). Sennett'e (2013) göre kamusal alan meydanlar ya da sokaklar gibi somut mekânlardır. Toplumsal yaşam alanları olarak vurguladıkları bu alanlarda kentlilerin özgürce iletişime geçebildiklerini vurgular. Jacobs'a göre kentsel açık alanlar kamuya açık erişilebilirlikleri sayesinde kentsel yaşam kalitesini yükselten ve kentsel iletişimi güçlendiren alanlardır (Jacobs, 1961).

Kentsel açık alanlar; tarımsal alanlar, ormanlar, fundalıklar, göller vb. gibi belirli bir arazi kullanımına yönelik veya sokak, park, bahçe, meydan, spor alanları, oyun alanları, rekreasyon alanları, doğal, tarihi, kültürel ve görsel değer taşıyan alanlar vb. gibi belirli fonksiyonlar yüklenmiş üzerinde yapılaşmanın olmadığı boş kentsel alanlardır. Kentsel açık alanların en önemli özelliği binaların arasında bir sosyal hayatı yani kentsel yaşamı oluşturmalarıdır. Kentsel açık alanlar kentsel yaşamın sağlıklı ve kaliteli bir şekilde sürdürülmesinde çeşitli görevlere sahiptir. Bu işlevler fiziksel, toplumsal, ekolojik, ekonomik, psikolojik ve estetik olarak oluşurlar. Kamusal alanlar kentlerin iletişim araçlarıdır, kentlilerin günlük ihtiyaçlarına hizmet ederler; çeşitliliği ve farklılıkları içerirler ve kentteki açık alan sistemini çeşitlendirirler. Kentlilerin psikolojik sağlığına katkıda bulunurlar. Kentsel açık alanlar enerji tasarrufu sağlama, turizm ve tarımsal iş imkânı sağlama, mülk değerini artırma ve üretim işlevleri açısından ekonomik işlevlere sahiptir. Ekolojik açıdan kentsel hava kalitesini iyileştirme, kentsel 1sı adalarını ve sera gazı etkisini azaltma, erozyon önleme, kentsel su döngüsünü sağlama, ekolojik restorasyonla biyolojik çeşitliliği koruma, kentsel gürültüyü azaltma gibi etkileri bulunmaktadır. Kültürel ve eğitici faaliyetler ile rekreasyonel olanak sağlayarak, toplumsal gelişmeye katkıda bulunarak, kentlerin estetik kalitesini artırarak, sosyal ve fiziksel anlamda kamu sağlığını koruyarak kentsel yaşama katkıda bulunmaktadırlar (Carr vd, 1992; Gehl, 1970; Moughtin, 1999).

Kentsel açık alanların kente sağladığı bu işlevlere rağmen endüstri devrimi sonrası gelișen kentlerde, modernizm ve postmodernizm süreçleri ile teknolojideki gelişmeler, neoliberal kentleşme ve küreselleşme ile beraber kentsel açık alanlarda niceliksel ve niteliksel anlamda değişimler gözlemlenmektedir. Alışılmış mekân ve zaman sınırlarının yok olması, ulaşım faaliyetlerinin gelişmesi ve genişleyen üretim alanlarına paralel olarak artan göçlerle birlikte kentleşme hızlanmıştır. Kentsel alanda bölgeler arası uzaklık kavramı ortadan kalkmıştır. Motorlu taşıtların kentsel erişimde üstünlük sağlamasıyla kentsel açık alanlar ve kentliler arasındaki ilişkiler değişime uğramıștır. Kentlerdeki kamusal mekânlar kullanılmayan boşluklara ve içerisinde günlük hayatın sergilendiği mekânlar yerine geçilip gidilen alanlara dönüşmüştür. Bununla birlikte küreselleşme, tüketim alışkanlıklarımızı da değiştirmiş ve kitlesel tüketim mekânları olan yeni kamusal mekânları oluşturmaya başlamıştır. Küreselleşmeyle birlikte kamusal mekânlar üzerindeki artan yönetim baskısı ile kamuda oluşturulan daha güvenli mekânlar algısı içerisinde kamusal mekânların kentin tüm gruplarına hitap eden çoğulcu yapısı ortadan kaldırılmıştır (Carmona, 2010). Kentliler boş zamanlarını kitlesel tüketim mekânlarında, sosyal iletişime girmeden metalaşmış tüketim ürünleri arasında geçirmektedir. Kamusal mekânlar da bu özelleşme ve ticarileşme ile şekillenmeye başlamıştır. Ticarileşme, kamusal mekanların kentsel yaşam ve kamusal mekân kalitesini artırmaktan çok, 
kâr üreten bir araç olarak kullanılmasına yol açmaktadır (Tibbalds, 1992). Özelleşme, kentliler arasında sınıfsal ayrıma neden olmakta, kamusal mekanlar kamusallığını kaybederek belli grupların mekanları haline gelmektedir. Son olarak sermayeye dayalı kentsel politikalar ve artan nüfustan kaynaklanan yapılaşma baskısından dolayı kamusal mekânlar niceliksel olarak azalarak sınırlı bir düzeye inmiștir.

\subsection{Kamusal Politika Aracı Olarak Alternatif Açık Alan}

Kamu politikası, toplumun bir ihtiyacını veya sorununu ele alarak, çözüm yollarını ve en uygun seçimi ortaya koyma ve bu sorunu çözme veya ihtiyacı karşılamaya yönelik, kamusal ya da diğer aktörlerin planlı kararlar ve eylemlerini içerir. Weimer ve Vinning'e (1998) göre kamusal kararlara ilişkin olarak, toplumsal değerlerin etkisinde oluşturulan kullanıcı odaklı tavsiyelerdir. Dye (1987) kamu politikasını hükümet bazında ele alarak, hükümetin yapmayı ve yapmamayı seçtiği eylemler olarak vurgular. Kamusal politikalar yasama, yürütme, yargı organları tarafından oluşturulduğu gibi kamu kurum ve kuruluşları ile siyasal partiler, çıkar grupları ve vatandaşlar tarafından da oluşturulabilir. Kamu politikası, kamusal kaynakların hangi kriterlerle, kimler tarafindan, hangi yolla ve kimler için paylaştırıldığını ele alır. Kamusal politika oluşum sürecine baktığımızda öncelikle toplum yararına çözülmesi gereken problem tanımlaması yapilır. Sonra probleme yönelik alternatif çözüm yolları ve seçenekler belirlenir. Seçeneklere yön veren amaç, ilke, ölçüt ve değerlerin kamu politikasını neden, nasıl ve ne ölçüde şekillendirdiği belirtilir. Daha sonra alternatif çözüm yolları arasından en uygunu kabul edilir. Kabul edilen politikanın özellikleri (ne, neden, nerede, ne zaman, nasıl ve kim tarafindan ve kim için?) belirtilir. Politikanın uygulanması ve değerlendirilmesi sonraki aşamalardır (Şekil 1). Uluslararası kuruluşlar, ülkenin siyasal yapısı, kamu yararını ya da özel girișimi önceleyen yaklaşımlar, farklı çıkar grupları arasındaki ilişkiler, hükümetin uyguladığı ekonomi politikası ve kamunun değişikliklere gös-

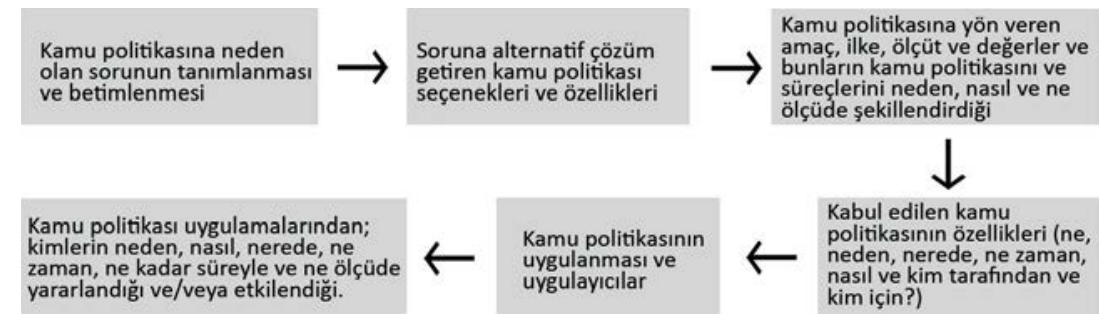

terdiği direnç, kamu politikası oluşumuna

Şekil: I

ve uygulanmasına etki eden diğer etmenler Kamu politikası olusum asamaları olarak siralanabilir.

Kentsel politikalar kamusal politikaların kentlere yansımış halidir. Kentsel problemler kentlilerin günlük kentsel yaşamlarını etkilemektedir. Farklı gruplara ait problemlerden oluşan kentsel sorunlar kentlerde mücadele alanlarını oluşturur. Bu nedenle tüm faktörleri içine alan, nesnel ve rasyonel bir politika sürecini geliştirmek zordur. Çok faktörlü karmaşık bir yapıya sahip kentsel sorunların giderilmesi için gerekli kentsel politikaları üretici ve uygulayıcı görevi üstlenen kamusal karar oluşturma sisteminin yasal ve siyasi yapısının üretilmesi gerekmektedir. Günümüzde kamu yararına çalışmayı unutan, küresel ekonominin taleplerine göre şekil alan kentsel politikalar ile kentler parçalara ayrılmaktadır. Kent ve kamusal alan birlikte çözülerek yok olmaktadır. Rant amacıyla kamu alanları özelleşmekte ve kentsel açık alanlar sermayeye dayalı kentsel politikalarla yok olmaktadır. Kentlilerin kentsel açık alan ihtiyacı çekmesiyle de kamusal mekânlar kentlerde farklı arayüzlerle karşımıza çıkmaktadır.

Alternatif kelimesi; fark, olasilık ve ötekilik demektir. Bir şeyi alternatif olarak ifade etmek, farklı olanı göstermek ve memnun olunmayan mevcut durumun geleceği için başka yollara işaret etmektir. Alternatif açık alanlarda, mekân oluşturmada alternatif tasarım ve müdahale yöntemleri ile kamusal mekânların geleneksel kullanımları kırılarak kamusal mekân için yeni bir biçim ve program yaratılır. Alternatif kamuoyu, egemen politikayı ya da söylemi istila eden veya dönüştüren alternatif kamusal mekânlarını yaratır. Mekânın yaratıcıları, bu alanın politik iletişimin standartlarını kırdığını vurgularken, ancak bazı katılımciların siyasi profesyonel 
faaliyetlerine ve bazı siyasi yaptırım ve politikalarında başlamalarına yardımcı olan da bu alternatif açık alan üretim deneyimidir (Fraser, 1992). Alternatif kamusal alan, sermayenin yeni küresel düzenlemeleri ve bunların ulus devletler kapsamında oluşturduğu problemlerin, dezavantajlılar lehine çözülmeye çalışıldığı söz ve eylemler alanıdır. Bu alan, ayrıca kentsel yaşamda kamu yararına verilen demokratik mücadele alanıdır (Özbek, 2004). Ryan'a göre alternatif kamusal alan burjuva kamusal alan kavramına meydan okuyan bir türdür. Alternatif kamusal alan, ulus-devletlerde küreselleşmeden kaynaklanan sorunların dezavantajlılar lehine çözmeye çalışan plan ve eylemlerden oluşur. Sınıfsal bir oluşum değildir ve bu alanda demokratik çabalar vermektedir (Negt, Kluge, 1993).

Kentlerdeki ihtiyaç eksikliklerine bir yanıt olarak, kamusal mekânlarda yeni tipolojiler, süreçler ve sahiplenme durumları ortaya çıkmaktadır. Gayriresmî olarak değiştirilmiş kamusal mekânlarla, bireyler, topluluk ve yapılı çevre arasında bir ilişki oluşur. Yer oluşturma (placemaking), kendin yap (DIY), taktiksel şehircilik (tactical urbanism), uyarlanabilir kullanım/tasarım (adaptive use) uygulamaları ile oluşturulan ve günlük yerlerle etkileşimi teşvik eden alternatif açık alanlar, kamusal mekânların fiziksel ve algılanabilir erişilebilirliğini ve sahipliğini değiştirmektedir. Alternatif açık alanlar geniş anlamıyla meydanlar, parklar, sokaklar gibi alışılmış kamusal alanlar dışındaki kentliler tarafından keşfedilen, tasarlanılan, kullanılan ve benimsenen alanlardır. Katılım ve yerel ifadeye ilham verme eğilimindedir. Alternatif açık alan vizyonları yeni katılımlara izin verir. $\mathrm{Bu}$ alanlar aracılığıyla, tasarıma kapsamlı yaklaşımlar örneklendirilir ve kamusal alanda toplum tarafindan paylaşılan deneyimler artar. Yenilikçi ve kamu yararına müdahale eden kentlilerin alternatif vizyonları sayesinde şehirde yeni gelecek senaryoları ve firsatlar ortaya çıkmaktadır.

Teraslar, çıkmaz sokaklar, üst geçitler, halka açık araziler ve binalar, tarihi kalıntılar, ada içi boşluklar, iç avlular ile kullanım dışı bırakılmış istasyonlar ve duraklar alternatif açık alan potansiyeline sahip alanlardandır. Paris'teki Les Grands Voisins sosyal konut dokusunun oluşturduğu iç avlu sistemi yerel kullanıcılar ve yerel hükümet ortaklığı ile kamusal mekâna dönüştürülmüştür. Giriş çıkışın serbest olduğu, yerel kullanıcılar için serbest zaman aktiviteleri sunan avluda çeşitli kamusal sanat ögeleri ve oturma birimleri bulunurken alanda zaman zaman küçük etkinlikler düzenlenmektedir. Cenevre'de bulunan Clos Voltaire sosyal konut dokusunda bulunan ada içi boşluklar çevrede oturanlar tarafından kullanılmaktadır. Doğal dokusu bozulmamış alan kent bahçeciliği, yürüyüş ve açık hava sineması gibi etkinlikleri içermektedir.

Londra'nın Peckham bölgesindeki çok katlı bir otoparkın çatı katı da kamusal mekâna dönüştürülmüştür. The Peckham Observatory seyir platformu, Londra silüetini ve çatıda kurulan enstalasyonlar için izleme imkânı sunmaktadır. Bölgede yaşayan insanlar için serbest zamanlarını geçirebilecekleri ve aktivite yapmaları-
Resim: I

Les Grands Voisins Iç Avlusu ve Clos Voltaire Ada Boşluğu (URL-I).
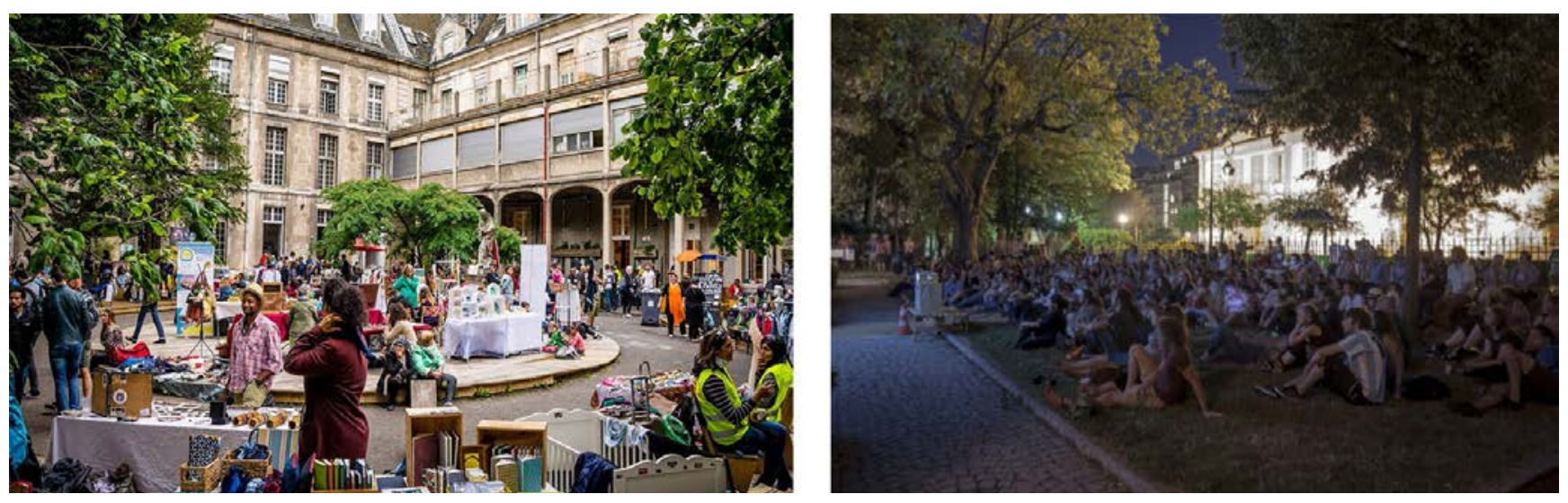
Resim: 2

The Peckham Observatory Seyir Platformu ve Here After Benzin istasyonu (URL-2).

Resim: 3

Queensway Alt Geçidi ve Paris'te bir tren istasyonu (URL-3).
Resim: 4

Danimarka'da kurulan ilk çatı çiftliği ve tasarlanmıs bir f̧ımaz sokak (URL-4).
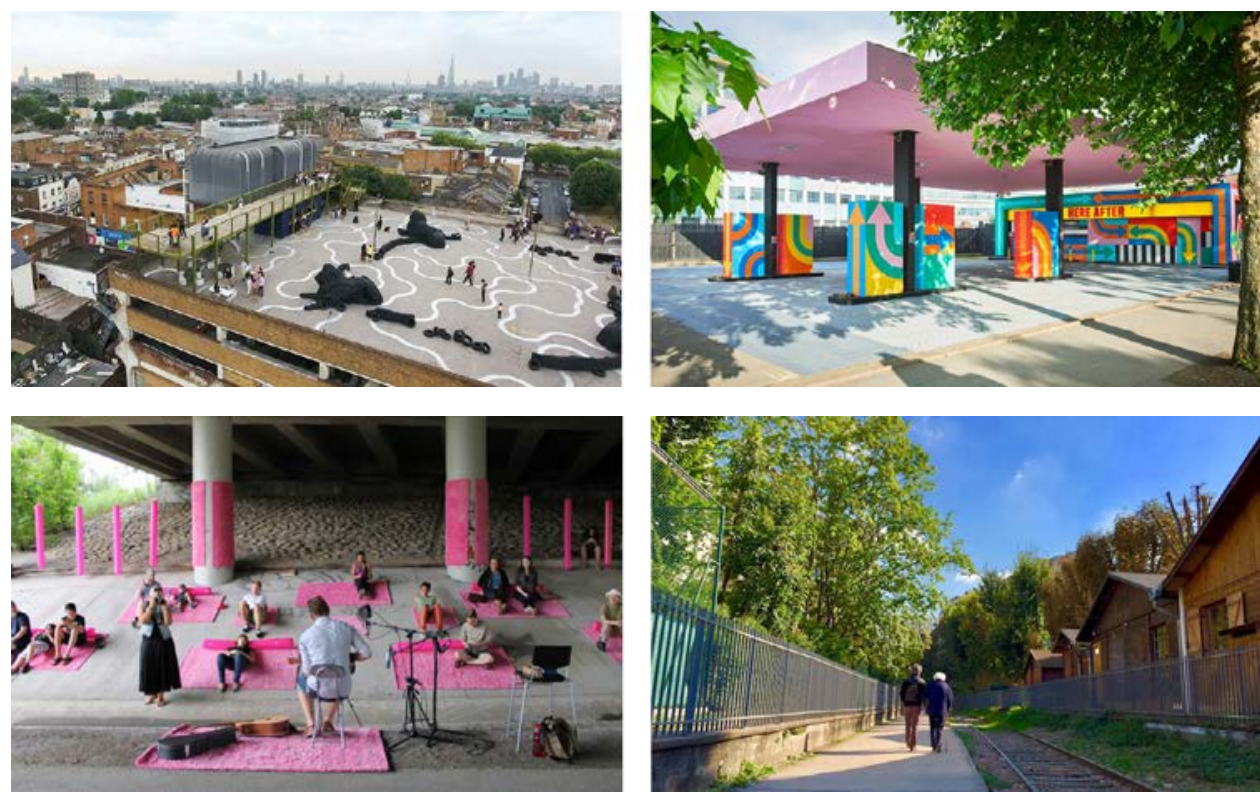

na imkân veren bir açık alandır. Londra, White City bölgesinde bulunan kullanılmayan bir benzin istasyonu halka açık sanat çalışması 'Here After' ile yeniden canlandırılmış ve bir kamusal mekâna dönüştürülmüştür. Dönüştürülen benzin istasyonunda çeşitli sanatsal etkinlikler düzenlenmektedir.

Ottava'da bulunan Queensway alt geçidi dönüştürülmeden önce normalde karanlık ve geçilip gidilen bir alandır. Yerel kullanıcılar arasından müzikle uğraşan bir grup kamusal mekâna sahip olmak ve yoldan geçenleri duraklatmak için alt geçitte Yeraltı Müzikali programı altında yapılan küçük dokunuşlarla alanı spor ve müzik yapılan bir yere dönüştürmüşlerdir. Paris’te düşük gelir gruplarının yaşadığ 1 bir bölgede bulunan ve artık kullanılmayan tren istasyonu bölge halkı tarafından rekreasyon alanına dönüştürülmüştür. Ekolojik

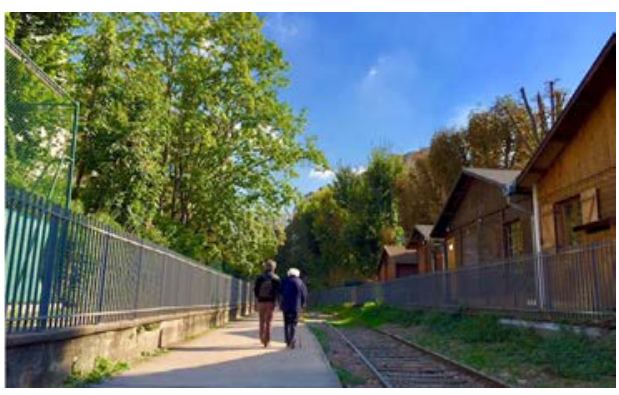

hayatı bozulmadan birakılan istasyon, yerel sanatçılar için bir kamusal sanat merkezi, çocuklar ve yetişkinler için de serbest zaman aktiviteleri sunmaktadır.

Danimarka'da kurulan ilk çatı çiftliği yerel gidanın, belediyenin ve yerel toplumun desteğiyle kentte üretilmesini sağlamaktadır. Danimarka'nın ilk çatı katı olan OsterGRO, 40 üye ailesine yerel ve sürdürülebilir şekilde üretilen yumurta, bal ve sebze tedarik etmektedir. Organik kentsel çiftlik, üç çalışanı, üyeleri ve gönüllüleri tarafindan yönetilmektedir. Diğer yandan sokaklarda çeşitli kentsel tasarım uygulamalarıyla kamusal mekân kalitesini artırıcı yönde geliştirilirken, çıkmaz sokak yer oluşturma ve kamusal sanat uygulamalarıyla bölge yaşayanların zaman geçirebileceği kamusal mekânlara dönüştürülmektedir.
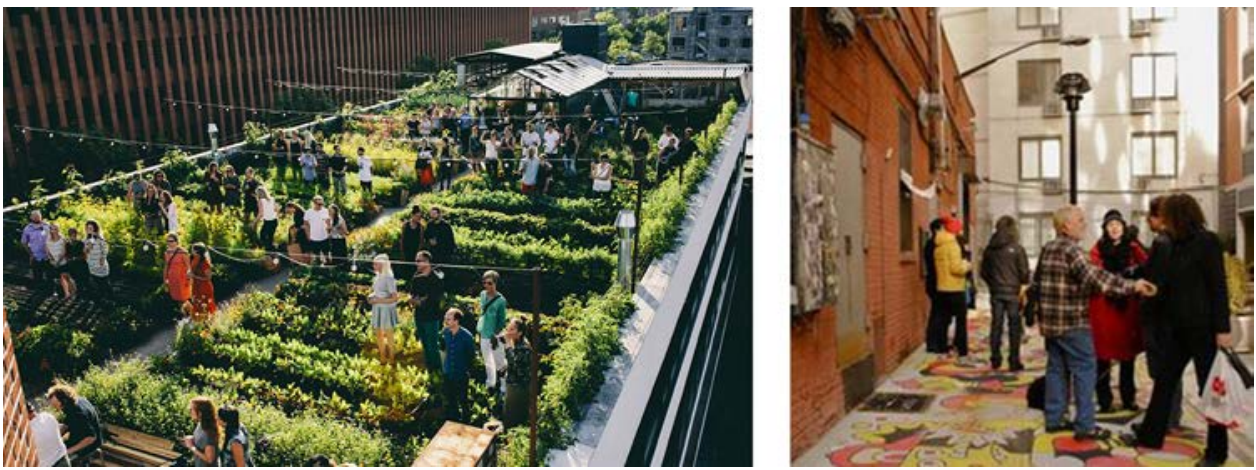


\subsection{Müzelerin Alternatif Açık Alan Olarak Ele Alınmast}

Kamu ve sanat insanlık tarihinin başından itibaren birbirleriyle ilişkili kavramlardır. Kamunun sanatla bir araya geldiği mekânlardan biri olan müzeler, dünya tarihinin sahip olduğu kültürleri gelecek kuşaklara taşıyarak kültürel beslenmeye ve geçmişi korumaya katk1 sağlar (Byrne, 1991). Doğada ve teknolojide yaşanan değișimler ve insanlığın gelişim süreci gibi konularda araştırmalar yapan ve bir arșiv oluşturan bilim merkezleri olarak tanımlanan müzelerin kentlerin sosyo-kültürel anlamda gelişiminde önemli katkıları vardır (Goulding, 2000).

16. yüzyıla kadar sanat aristokrasinin/kilisenin gözetimi altında şekillenmiştir. Fransız İhtilali ve Aydınlanma hareketiyle birlikte aristokrasinin/kilisenin kamuya baskısının yıkılmasıyla birlikte sanatçılar baskıdan kurtularak kendilerini özgürce ifade etmeye başlamış ve sanat kısıtlamalardan kurtulmuş ve toplumun tüm kesimlerinde sergilenmeye başlamıştır (Şentürk, 2012). Öncesinde farklı müzeler kamuya açılsa da, kamusal müze ilk kez Louvre Müzesi ile benimsenmiștir. Fransa'da, halkın 1793'te kraliyet koleksiyonuna el koymasıyla birlikte müze kamu malı olur. Halkın kamusallığı olușturmaya çalıșması ve sonucunda kamusal müzelerin ortaya çıkıșı, sanatı toplumla yakınlaştırma çabası olarak olumlu bir gelișme kabul edilebilir. Habermas da kamusal alan tanımını bu süreçten beslenerek yapmıștır. Artun (2008) sergi ortamları ve müzeleri, zamanla eleștirinin büyüdüğü, sanatla ilgili kuramların geliştiği birer kamusal mekâna dönüştüğ̈̈n̈̈ savunmuștur.

Günümüzde çağdaş müzecilik anlayıșı pazarlama, reklam ve halkla ilișkiler temelleri üzerine kurulmuştur. Bu temeller üzerine kurulan Postmodern müzecilik anlayışı da müzeyi milli ideoloji ve toplumsal belleğe ait ögelerin gelecek kuşaklara aktarıldığı, korunan/koruyucu mekân olarak tanımlayan modern müzecilik anlayışının tam tersini simgeler. Bu yeni görünüm, küreselleşmenin getirdiği tüketim toplumunun müzelere yansıması olarak da değerlendirilebilir. Yeni müze ve sergileme pratikleri ile değișen izleyici beklentileri ve davra- nışları bunun örneklerindendir. Modern müzecilik otoriter tutumu simgelerken, postmodern müzecilik paylaşımı/karşılıkl1ğ1 simgeler (Artun, 2008).

Sahip oldukları açık alanlar müzelerin kimliğini ve bulunduğu bölgeyle olan bütünlügünü sağlayan faktörlerden biridir. Kentsel tasarımda birçok alt birimde görüldüğü gibi müze çevrelerinde de; araziyi, konfor özelliklerini, binanın konumunu, ziyaretçiyi yönlendiren farklı araçları, ilgi ve kullanıcıları teşvik etmeyi de içine alan fiziksel ve sosyal bir mekân oluşturulmalıdır. Bununla birlikte müzelerin açık alanları kentlilerin açık alan ihtiyaçlarını karşılayan anlamlı bir yerlere dönüşebilir. Dolayısıyla, müzeler, bulunduğu bölge ile bağlantısını sağlayan açık alanlarıyla birlikte tasarlanmalı ve kullanıcıların zaman geçirmesini sağlayan düzenlemeler yapılmalıdır (Broadhurst, 1989). Günümüzde müzeler kentle doğrudan etkileşim kurarak, farklı kullanıcı gruplarını çeşitli etkinliklerle bir araya getirebilen kültürel çekim noktaları haline gelmektedir. Bu yapıların mülkiyet alanları içerisinde veya yakın çevrelerinde bulunan ve güçlü bir potansiyele sahip olan açık alanların kentsel mekân örüntüsü ile bütünleşmiş bir biçimde ele alınarak tasarlanması, kentsel yaşam kalitesi üzerinde pozitif etkilere sahip olmaktadır. Farklı ülkelerde, kapalılık/içe dönüklük olgusunu ve erişim kısıtlılığını kırarak kamusal-özel mekân ayrımını farklı boyutlara taşıyan birçok müze örneği bulunmaktadır. Bu müzeler, binaları dışında kalan açık alanlarını kentsel yaşama herhangi bir erişim engeli olmadan dâhil ederken, alternatif etkinliklere de ev sahipliği yapmakta ve kentlilere sosyal aktivite ihtiyaçlarını karşılayabilecek yeni firsatlar sunarak gündelik yaşamın bir parçası olmaktadırlar. Bu bağlamda da kentsel yaşama alternatif bir ara yüz olarak katkı sağlamaktadırlar.

Dünya genelinde açık alanlarını kamusal kullanıma açan müze örnekleri incelendiğinde alternatif açık alan kullanımına sahip müzelerin belli fiziksel çevre, sosyal çevre ve çevresel algi altında ortak kriterleri bulunmaktadır (Tablo 1). Kriterlerdeki çeşitlik ve yoğunluk arttıkça müze açık alanlarının 
kullanımı yoğun olmaktadır. Fiziksel çevre anlamında müze açık alanlarında mekân tarafından kullanıcıya yönelik sağlanan hizmet ve sosyal alandaki kullanımların ve kullanıcının yapabildiği gerekli, opsiyonel ve sosyal aktivite çeşitliliği önemli bir yer tutmaktadır. Aktivitelerin ve kullanımların devamlılığının sağlanması ve kullanıcılara alternatif seçeneklerin sunulması da mekânın kullanımında sürekliliği sağlamaktadır. Müzelerin açık alanlarının bulundukları bölge ile geçirgen bir yapıya sahip olması alternatif açık alan oluşumunu bölgesi ile bağlantılar kurmasından yararlanarak desteklemektedir. Ayrıca alternatif açık alana erişimde yaya, engelli ve toplu taşıma yönünden çeşitliliğin olması mekânın kullanımını artırmaktadır. Müze açık alanlarının sosyal çevre yapısı kullanıcı çeşitliliği ve kolektif üretim firsatlarıly zenginleşmektedir. Alternatif açık alanlardaki iletişim ve etkileşim süreci müzelerin açık alanlarını kentliler arasında iletişim kurmayı sağlayan yeni mekânlar olarak ortaya çıkarmaktadır. Alternatif açık alan oluşumunu destekleyen bir diğer sebep oluşturulan yeni mekânların bölgedeki komşuluk ilişkilerine katkı sağlamasıdır. Mekân oluşumu ve kullanımının artmasıyla bölgede sosyal ve ekonomik anlamda bir gelişme

Tablo: I

Alternatif açık alan özelliğine sahip müzelerin özellikleri. yaşanmaktadır. Ayrıca mekânda sunulan

kullanımların ve aktivite hizmetlerinin ödenebilirliğinin adil olarak yayılması da oluşumu desteklemektedir. Alternatif açik alanlarda kentlilerin sahip olduğu çevresel algı da mekân kullanımını etkilemektedir. Alternatif açı alan oluşumunda müzelerin açık alanları güvenlik ve önlem amaçlı belirli saatler arasında kullanımı sınırlandırılmaktadır. Açık alanların kullanıcılarına sağladıkları konfor hissi, içinde bulundukları bölgenin güvenliği ve çevresel kalitesi de kentlilerin alternatif açık alan kullanımını etkilemektedir. Son olarak müzelerin taşıdığı çekicilik değerleri ve toplumsal bellekte bir değere sahip olması mekân kullanımını güçlendirmektedir.

\section{3. İstanbul'da Müzelerin Alternatif Açık Alan Olarak Kullanılması}

İstanbul'daki müzelerin açık alan varlığının ele alındığı bu bölümde; İstanbul Merkezi İş Alanı ve 1. Derece Merkezler içinde yer alan, aynı zamanda 2009 İstanbul Çevre Düzeni Planı kapsamında tanımlanan 'Kültür Endüstrileri' alt bölgesi ve yakın çevresi içinde konumlanan müzeler ve kamusal açık mekânlar incelenmiştir. Yapılan analizler sonucu etki alanlarıyla kentsel yaşam üzerinde pozitif etki gösteren alt çalışma alanlarındaki alternatif açık alan varlıklarının nitelikleri detaylandırılmıştır. Alanda uygulanan anket çalışması ve bunun sonuçlarının değerlendirilmesi yapılmış ve alandaki

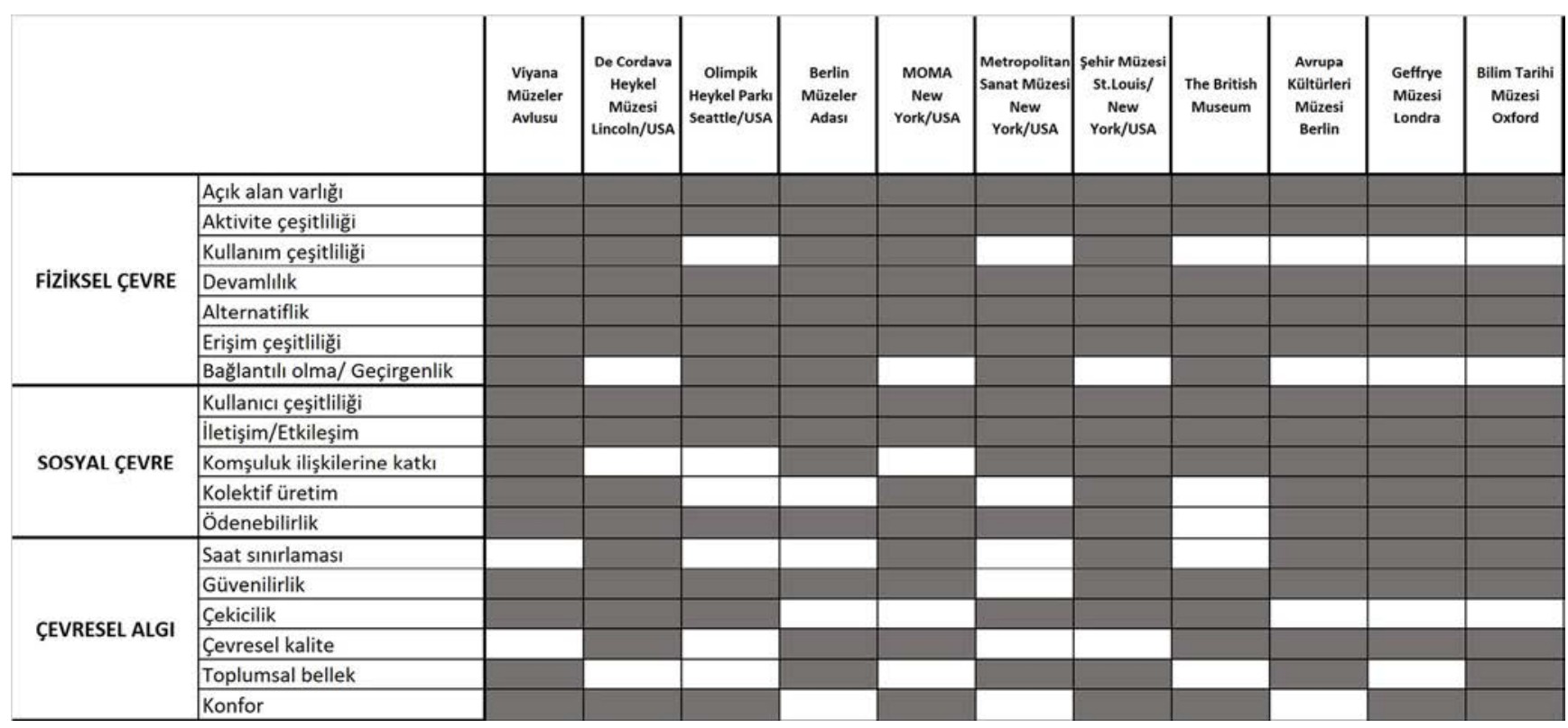


alternatif açık alan potansiyeli ile ilgili çıkarımlar elde edilmiştir. Bölüm sonucunda yapılan araştırmalar genel anlamda değerlendirilmektedir.

İstanbul'daki kentsel açık alanlar çalışma kapsamında meydanlar, aktif yeşil alanlar ve pasif yeşil alanlar olarak ele alınmıştır. Aktif yeşil alanlar spor alanları, rekreasyon alanları, korular, mahalle parkları gibi alanlardan oluşurken, pasif yeşil alanlar mezarlıklar ve yapılaşmaya açılmamış doğal yapısını koruyan açı alanları içermektedir. Yoğun bir yapılı çevrenin bulunduğu çalışma alanında rekreasyon ve açı alan hizmetinden yararlanamayan mahalleler bulunduğu görülmektedir (Şekil 2). 500 metrelik yürüme mesafesi dahilinde yapılı çevreye hizmet vermesi beklenen aktif yeşil alanlardan özellikle spor alanlarının çalışma alanının büyük bir kısmında yetersiz sayıda olduğu görülmektedir. Çalışma alanı, park, rekreasyon alanı ve spor alanları açısından niceliksel olarak yetersiz durumdadirlar. Park kullanımlarının birçoğu çocuk parkı ölçeğinde olmakla birlikte farklı kullanıcı gruplarına hizmet sunulan alternatif çeşitliliğin olmadığı görülmektedir. Kentin kozmopolit yapısına hizmet vermesi beklenen rekreasyon alanlarının çalışma alanında adil bir şekilde yayılmadığı görülmektedir. İletişim ve etkileşim merkezi olan ve kentsel açık alanların da önemli bir ögesi olan meydanların çalışma alanı sınırları içerisinde sayılı sayıda olduğu görülmektedir.

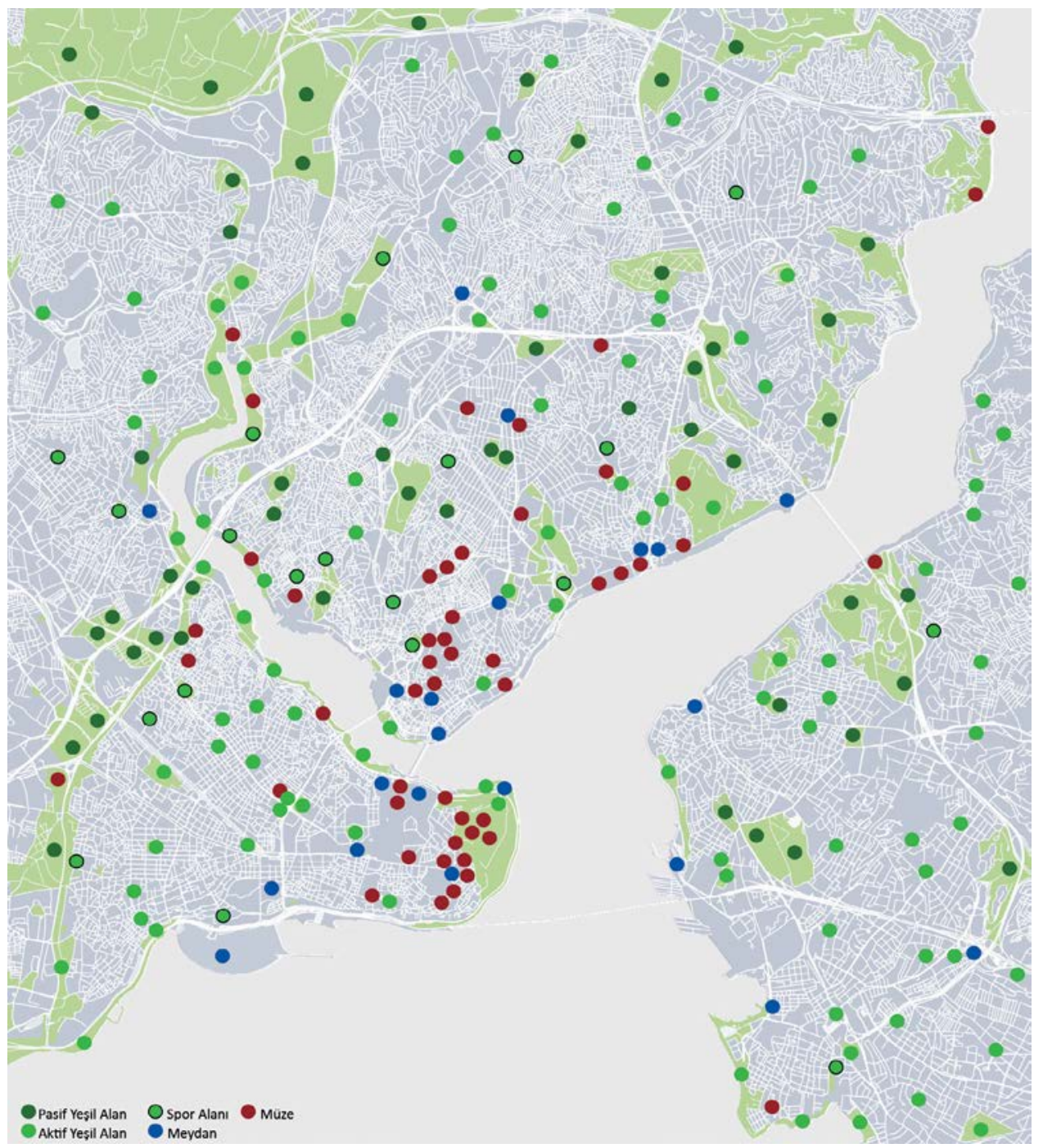


Şekil: 3

Kentsel açık alanların etki alanları.
Tespit edilen kentsel açık alanlarda meydanların ve aktif yeşil alanların 500 metrelik yürüme mesafesinde etki alanları çıkarılmıştır. Yapılaşmanın yoğun olduğu Fatih, Beyoğlu, Şişli, Beşiktaş, Üsküdar ve Kadıköy ilçelerinde açık alanların etki alanlarının yapılı çevre için yeterli olmadığ 1 görülmektedir (Sekil 3). Mevcutta nicel olarak az sayıda bulunan kentsel açık alanlar 500 metrelik etki alanlarına giren kentsel yoğunluğa sağlıklı bir erişilebilirlik sağlayamamaktadır. Kentsel açık alan çeşitliliğinin azlığı ve mevcut açık alanların 500 metrelik etki alanlarının yeterli olmaması; farklı yaş gruplarından kentli kullanıcıların oyun, rekreasyon aktivite ve iletişim imkânlarına, kent sağlığına, kentsel kimliğe, sürdürülebilirliğe ve ekonomiye zarar verdiği için İstanbul'un kentsel yaşamı için önemli bir problemdir. Kentsel açık alanların İstanbul'da kentsel alana sağlıklı ve adil bir şekilde hizmet verecek şekilde planlanamaması da önemli bir sorundur.

İstanbul'da Tarihi Yarımada, Haliç kıyı bölgesi, Galata-Pera bölgesi ve Şişli-Beşiktaş ilçelerinde, tarihi veya modern niteliğe sahip, müzecilik literatüründe sahip oldukları koleksiyonlar doğrultusunda yapılan sinıflandırmaya göre 6 tane genel müze, 11 tane sanat müzesi, 8 tane bilim ve teknoloji müzesi, 3 tane sanayi müzesi, 10 tane anıt müze, 3 tane tarih müzesi, 1 tane arkeoloji müzesi, 1 tane açık hava müzesi, 2 tane müze ev ve 1 askeri müze bulunmaktadır

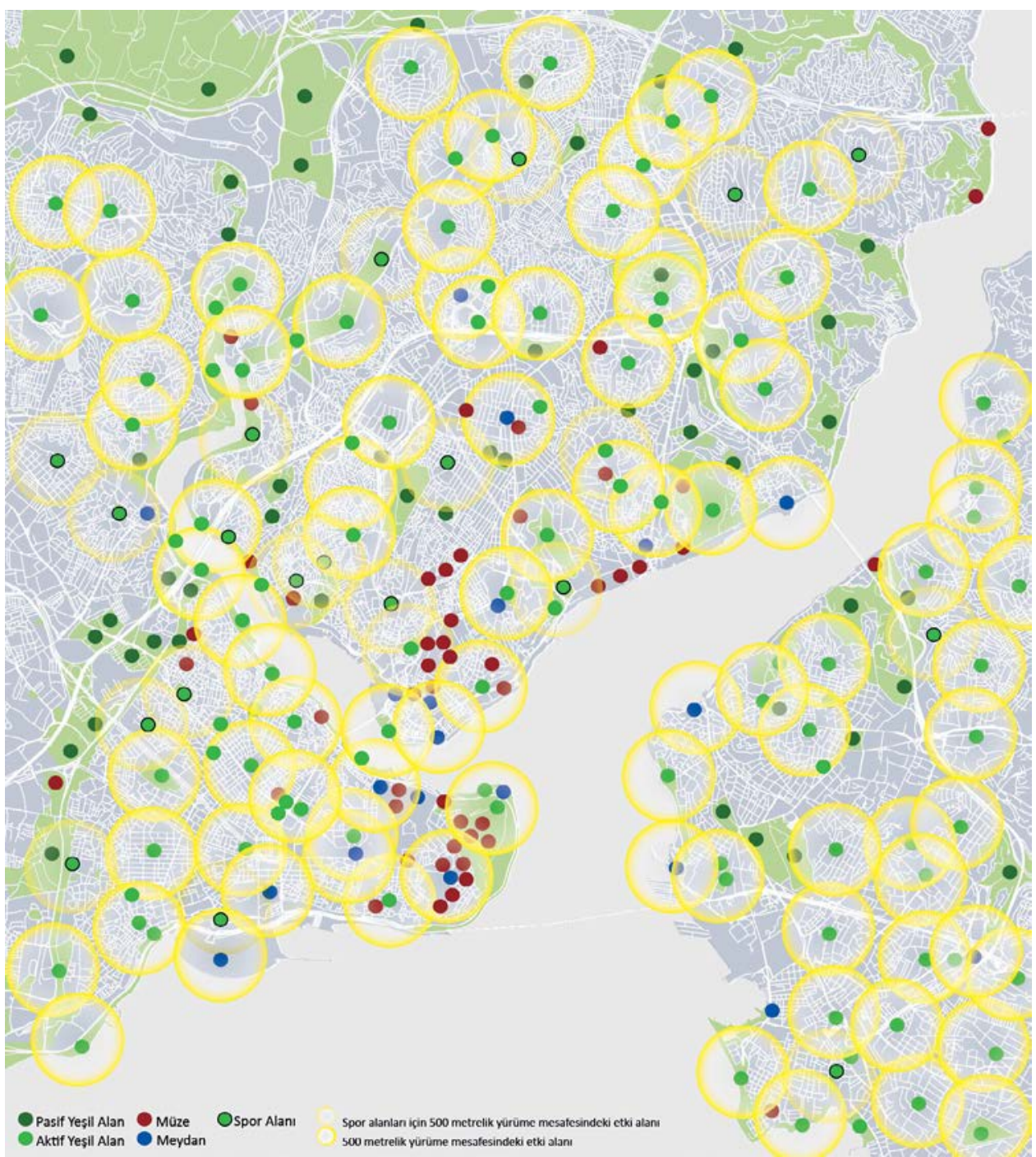




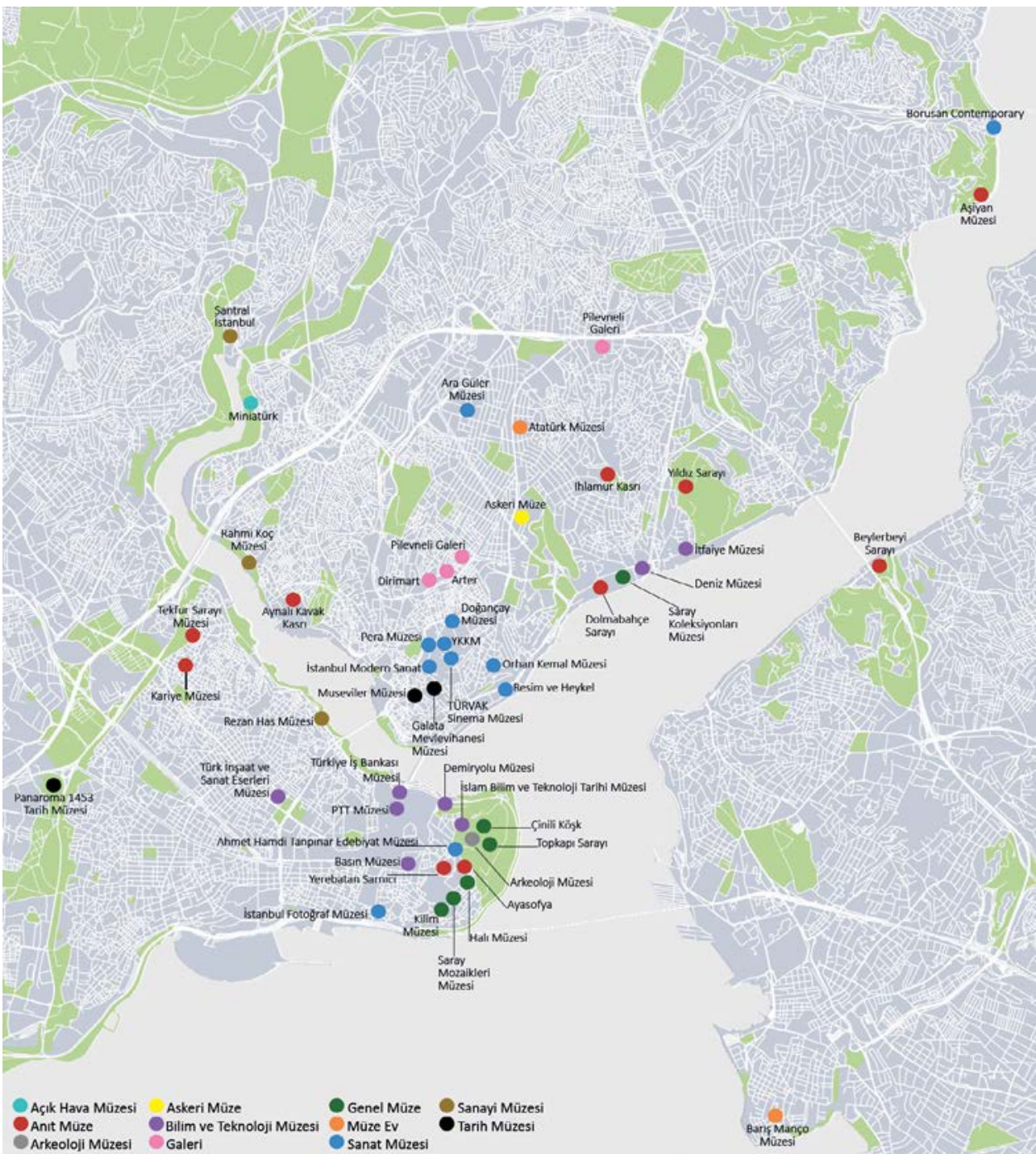

(SSekil 4). Farklı koleksiyonlara sahip bu müzeler kentin kozmopolit yapısına hizmet verirken kentliler için farklı anlamlar da ifade etmektedir. Postmodern müzecilik anlayışı ile birlikte Türkiye'deki müzecilik anlayışı da değişime uğramış ve müzelerin vizyonu ziyaret odaklı olmaktan çıkıp kentliler için yaşayan ve yaşanılan müzelere dönüşmüştür (Artun, 2008). Müzeleri, kullanıcıların kullanabildiği, zaman geçirebildiği, deneyim kazanabildiği mekânlar haline getirmek yeni müzeciliğin yeni hedefi olmuştur. Bu kapsamda İstanbul'daki müzelerde farklı gruplardan insanların, alternatif mekânlarda birlikte zaman geçirme, kolektif üretim ve kamusal sanata yönelik katkı sağlayabilecekleri etkinlikler düzenlenmeye başlamıştır. Bu etkinliklere
Arkeoloji Müzesi Konserleri, Ara Güler Müzesi Açık Hava Sinemaları, Rahmi M. Koç Müzesi Çocuk Atölyeleri örnek olarak gösterilebilir. Kültür ve Turizm Bakanlığı, İstanbul Büyükșehir Belediyesi, sivil toplum kuruluşları, üniversiteler ve müzeler iş birliğiyle düzenlenen etkinlikler, her yaş ve gruptan insana alternatif sosyal hizmet sunulmaktadır. Düzenlenen etkinlikler, aktiviteler ve çalıştaylar ve bienallerle müzeler kentin günlük hayatına dahil edilmeye çalışılmaktadır.

Postmodern müzecilik anlayışı ile birlikte müzelerin sosyal altyapısı desteklenmeye çalışılsa da çalışma kapsamında incelenen müzelerin çoğu geçirgenlik ve erişilebilirlik bakımından bakımından zayıf olup, yakın çevreleri ile mekansal bir bütünleşme
Şekil: 4

Müze türleri. 
Şekil: 5

Müzelerin açık alan varlığı. sağlayamamaktadır. Çalışma alanı sınırları içerisinde bulunan 50 adet müzenin 28 tanesi kendi açık alanlarına sahip iken 22 tanesinde açık alan bulunmamaktadır (Şekil 5).

Açık alanlara sahip müzeler, bulundukları bölgelerde 500 metrelik yürüme mesafesi baz alınarak oluşturulan açık alan etki analizine dahil edildiğinde daha önce sadece aktif yeşil alanlardan olan meydanlar ve parklar, oyun alanları, rekreasyon alanları, korular ve spor alanlarından oluşan etki alanlarının İstanbul üzerinde dağılımında artış olduğu gözlenmektedir (Şekil 6). Haliç'te müzelerin alternatif açık alan olarak ele alınmasıyla, kıyı boyunca var olan açık alanlar arası yaya erişimin arttırılabileceği görülmektedir. Açık alanlarının İstanbul'un kentsel yaşamına katılımıyla bu müzeler yaşayan mekânlara dönüşecektir. Galata-Pera bölgesinde Galata Mevlevihanesi Müzesi ve İstanbul Resim ve Heykel Müzesi'nin açık alan kullanımına katılımıyla kentliler için alternatif açık alan oluşturulmuştur. Mevcut kentsel açık alanların ihtiyacı karşılamakta yetersiz olduğu görülen Şişli ilçesi Merkez mahallesinde Ara Güler Müzesi, alternatif kamusal açık alan olarak kente dâhil edilmesi ile bölgedeki kentsel açık alan ihtiyacının karşılanmasına katkı sağlamaktadır. Zeytinburnu'nda bulunan Panorama 1453 Tarih Müzesi, rekreasyon alanları ve pasif yeşil alanlarının bulunduğu Merkez Efendi Mahallesi'nde bir geçiş alanında bulunmaktadır. Müzenin açık alan sistemine eklemlenmesiyle bölgede

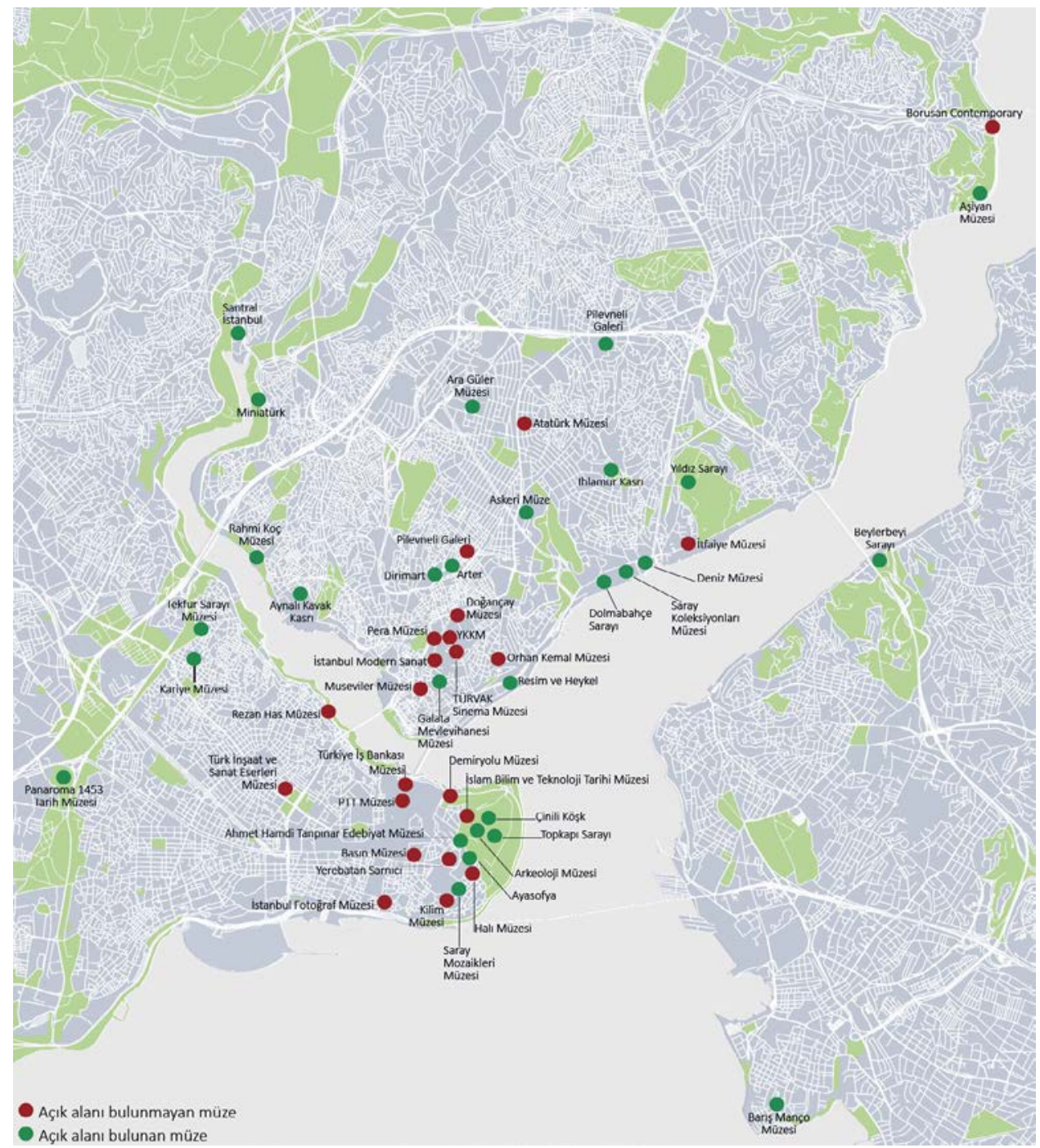


mekânlar arası geçirgenlik artacaktır. Tarihi yarımada ve Beşiktaş'ta müzelerin açık alanlarının etki analizine dahil edilmesiyle pozitif yönlü bir katkı gözlemlenmektedir. Ayrıca müze sinıflandırılmasında bulunmasa da Dirimart ve Arter Sanat Galerilerinin oluşturduğu etki alanları da Beyoğlu'nda Dolapdere bölgesi için potansiyel bir etki alanına sahiptir. Müzelerin açık alanlarının, bulundukları bölgelerdeki kamusal açık alanlar olarak kullanılmaları durumunda yürüme mesafelerine ve yaya erişimine olan olumlu etkilerinin ortaya konduğu analizde Zeytinburnu'nda bulunan Panorama 1453 Tarih Müzesi, Beyoğlu'nda bulunan Rahmi M. Koç Müzesi ile Miniatürk, Şişli'de bulunan Ara Güler Müzesi ve Beşiktaş'ta bulunan Deniz Müzesi'nin etki alanları içerisinde olumlu etki yaratabilecek potansiyele sahip olduğu görülmektedir.

\subsection{Panorama 1453 Tarih Müzesi, Rahmi M. Koç Müzesi, Miniatürk, Ara Güler Müzesi ve Deniz Müzesi Etki Alanları Incelemeleri}

2009 yılında açılan Panorama 1453 Tarih Müzesi 'dünyanın ilk tam panoramik müzesi' olma unvanını taşıyor. Farklı medeniyetlerin katkılarıyla oluşan İstanbul'un geçmişini anlatmak üzere kurulmuş bir tarih müzesidir. Müze, kuşatmanın geçtiği Topkapı-Edirnekapı surlarının karşısında Zeytinburnu'nda Merkez Efendi Mahallesi'nde bulunmaktadır. Metro, tramvay ve otobüs seçenekleriyle toplu taşıma ile

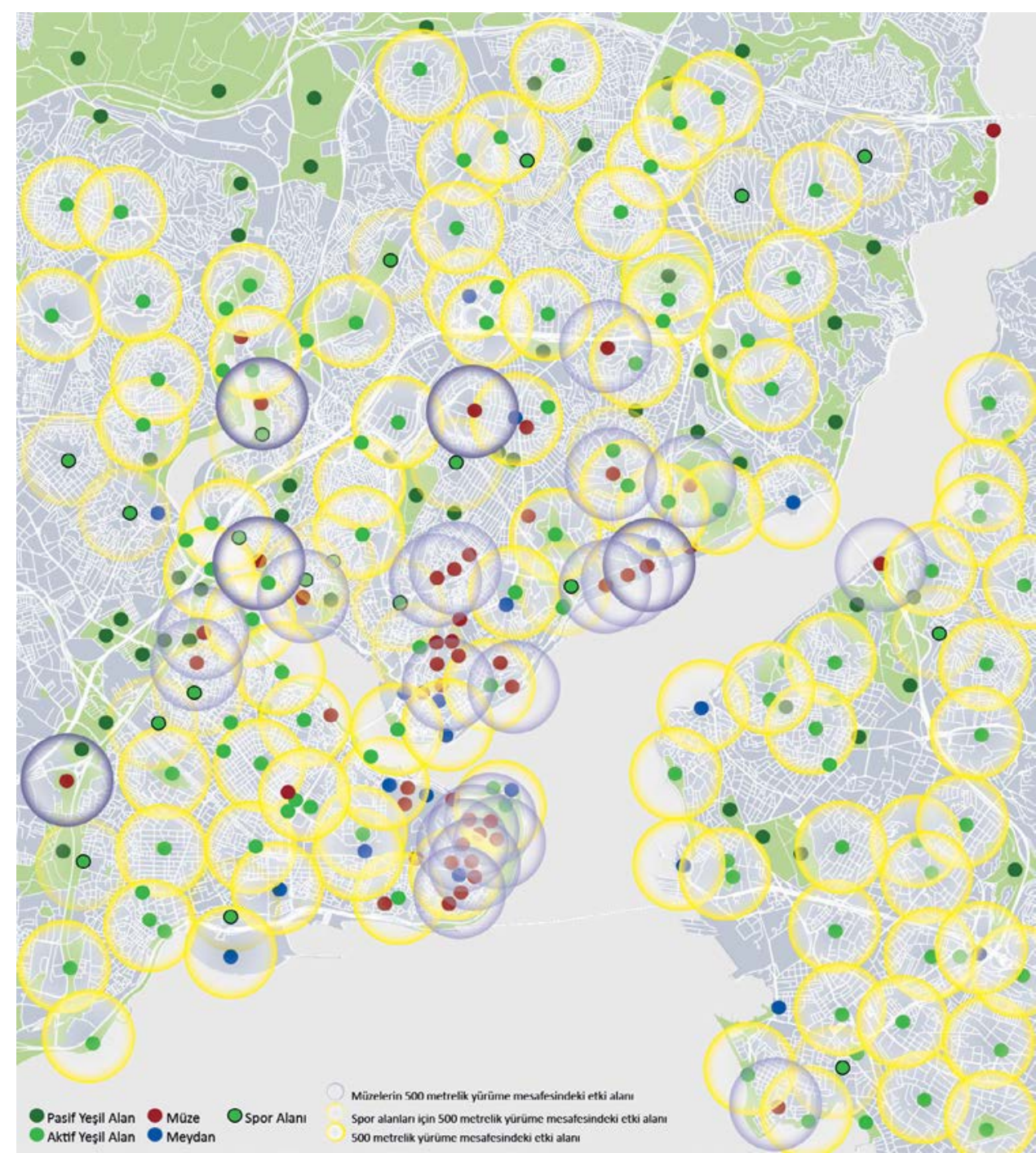

Şekil: 6

Kentsel açık alanların etki alanları. 
erişim açısından çeşitliliğe sahiptir. Yakın geçmişte Trakya Otogarı'nın bulunduğu alan, otogarın taşınmasıyla birlikte büyük bir parka dönüştürülmüş ve Panorama 1453 Tarih Müzesi de Topkapı Kültür Parkı'nın bir parçasını oluşturmaktadır. İBB Kültür A.Ş. tarafindan işletilen müze hafta boyunca 08.00-17.00 saatleri arası hizmet verirken kullanıcılara müzenin yer aldığ 1 Topkapı Kültür Parkı içerisinde dinlenme ve eğlenme imkânı da sunulmaktadır. Müzenin bulunduğu Topkapı Kültür Parkı hafta içi daha çok yakın çevresine hizmet verirken, hafta sonu ziyaret amaciyla gelen kullanıcılara da hizmet vermektedir. Müzenin etki alanını oluşturan Merkez Efendi Mahallesi'nin 2019 TUIK verilerine göre nüfusu 23.742 kişidir. Bölgede aktif yeşil alanlar, rekreasyon alanları ve iç kesimlerdeki çocuk parklarından oluşurken, pasif yeşil alanlar, mezarlık ve doğal bitki örtüsünü koruyan yeşil alanlardan oluşmaktadır (Şekil 7). Bölgede yeşil alanlar dışında kentsel açık alan bulunmamaktadır. 2003 yılında ziyarete açılan Miniatürk, İstanbul Büyükşsehir Belediyesi Kültür A.Ş. tarafindan işletilen bir açık hava müzesi olarak Anadolu'nun geçmişinde bulunan tüm değerlerle birlikte, yakın coğrafyada yaşamış medeniyetlerin izlerini İstanbul'da Beyoğlu'nda sergilemektedir. Hafta boyunca saat 09.00-18.00 arası hizmet vermektedir. Metrobüs, otobüs ve minibüs gibi toplu taşıma seçenekleriyle erişimin sağlandığ müzede maketlerin yer aldığı alanın yanı sira otopark, restoran, kafeterya, hediyelik eşya, açık hava gösteri alanı, çocuk oyun parkı gibi hizmet alanları bulunmaktadır. Miniatürk, 2019 TUİK verilerine göre 10.556 kişilik bir nüfusa sahip Örnektepe mahallesinde bulunmaktadır. Haliç kıyısını oluşturan rekreasyon alanları bölgenin kentsel açık alan kalitesini yükseltirken kıyıda bulunan resmi kurumlar ve otopark alanı gibi kullanımlar kentsel açık alanlar arasındaki bağlantıları kopararak kıyıdaki sürekliliği engellemektedir (Şekil 8). Bölgedeki kentsel açık alanları, kıyıdaki spor alanları, rekreasyon alanları ve iç kesimlerdeki çocuk parkları oluşturmaktadır. Topografik özelliklere sahip ağaçlandırılmış alanlar pasif yeşil alanları oluşturmaktadır. 1994 yılında ziyarete açılan ve Rahmi M. Koç Müzecilik ve Kültür Vakfi bünyesinde yer alan Rahmi M. Koç Müzesi dünyada geçmişten günümüze endüstri ve mühendislikle ilgili nesnelerin ve belgelerin toplanması, arşivlenmesi, araştırılması, korunması ve sergilenmesini amaçlayan bir sanayi müzesidir. Müze koleksiyonunda genel başlıkları ile iletişim ve ulaşım altında yer alan endüstriyel mirasının geniş kapsamda örnekleri yer almaktadır. Pazartesi günleri hafta içi 09.30-17.00 hafta sonu 09.30-18.00 arası hizmet vermektedir. Haliç'in kuzey yakasında Beyoğlu'nun 2019 TUIK verilerine göre 15.706 kişi nüfuslu Piri Paşa Mahallesi'nde yer almaktadır. Bölgedeki aktif yeşil alanlar Haliç'in kıyısındaki spor alanları ve rekreasyon alanları ile iç kesimdeki spor alanlarından oluşmaktadır. Ayrıca topografik özelliklere analizi.

şekil: 8

Miniatürk yakın çeure analizi.

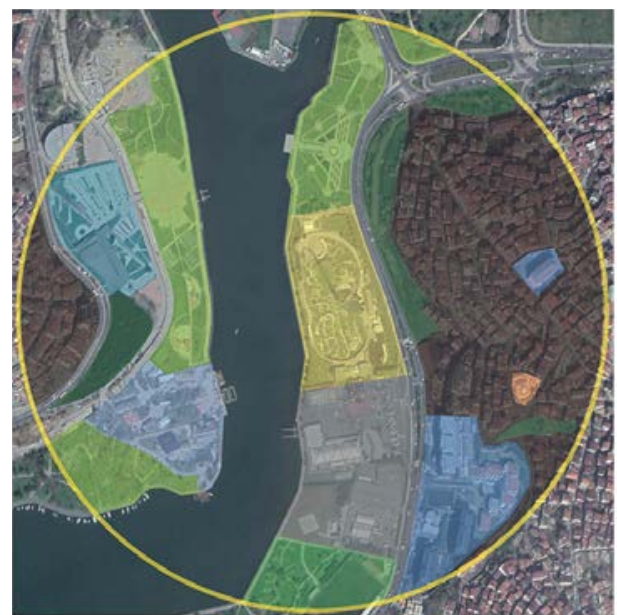

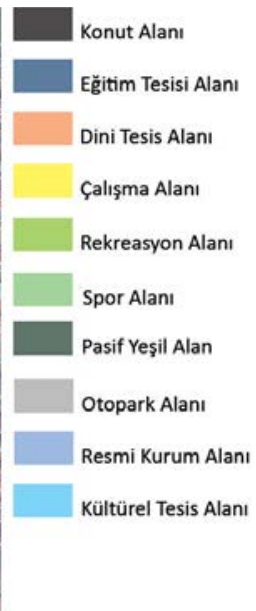


sahip doğal bitki örtüsünü koruyan alan bölgenin pasif yeşil alanlarını oluşturmaktadır (Şekil 9). Rahmi M. Koç Müzesi sosyal yapısını güçlendirmek amacıyla üniversiteler ve ilkokullarla kurduğu ilişkiler sonucu çocuklara ve gençlere ücretsiz atölyeler düzenlemektedir.

Tarihi Bomonti Bira Fabrikası yerleşkesinde bulunan Ara Güler Müzesi, Ara Güler arşivinin bütün olarak korunması ve gelecek kuşaklara aktarılmasını, bu süreçte fotoğraf sanatının bu arşiv üzerinden desteklenmesini hedefleyen bir sanat müzesidir. 2018 yılında ziyarete açılan müze Pazartesi günleri hariç 10.00-18.00 arası hizmet vermektedir. Şişli'de 2019 TUIKK verilerine göre 13.654 nüfuslu Merkez Mahallesi'nde yoğun bir yapılaşma görülürken bölgede kendi açık alanlarına sahip kapalı sitelerin yeşil alanları dışında kamu kullanımına açık herhangi bir kentsel açık alan bulunmamaktadır (Şekil 10). Müzede ücretsiz olarak söyleşiler, açık hava film gösterimleri ve paneller düzenlenmektedir. Müzenin içerisinde bulunduğu avlu çevresindeki birimlerin ve müzenin etkinliklerine ev sahipliği yapmaktadır.

2013 yılında, günümüzde kullanılmakta olan binasında hizmete açılan Deniz Müzesi, Türkiye 'nin denizcilik alanında en büyük bilim ve teknoloji müzesidir. Denizcilik tarihine ait zengin bir koleksiyonları bulunmaktadır. Hafta içi 16.00, hafta sonu 17.00 saatlerinden sonra müzeye ziyaretçi girişi yapılmamaktadır. Erişilebilirlik açısından toplu taşıma yönüyle zengin bir
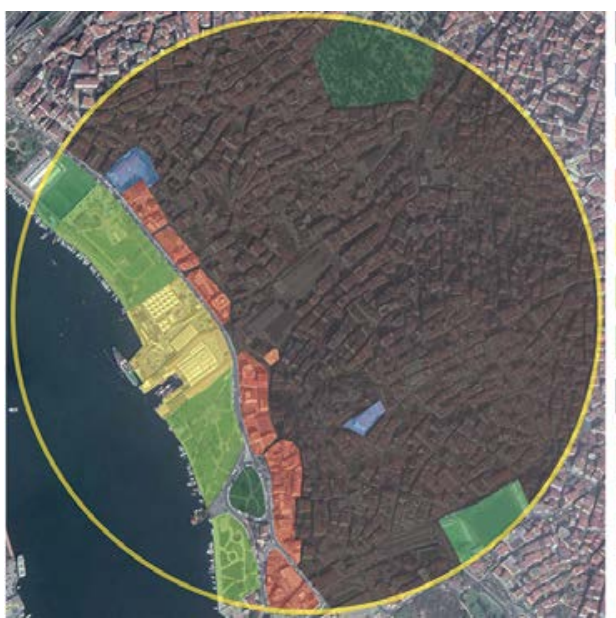

çeşitliliğe sahiptir. Müze, Beşiktaş ilçesinin 2019 TUİK verilerine göre 2534 nüfuslu Sinanpaşa Mahallesi'nde bulunurken bölgede $6425 \mathrm{~m}^{2}$ 'lik bir meydan ve parklardan oluşan aktif yeşil alanları mevcut ve pasif yeşil alan bulunmamaktadır (Şekil 11).

Çalışma alanında kentsel açık alanların 500 metrelik erişebilirlik çapları analiz edildiğinde, kent içerisinde etki alanları kapsamına girmeyen ve yeterli etki alanı bulunmayan alanlardan seçilen Panorama 1453 Tarih Müzesi, Rahmi M. Koç Müzesi, Miniatürk, Ara Güler Müzesi ve Deniz Müzesi ve bu müzelerin 500 metrelik yürüme mesafesindeki yakın çevreleri incelenmiştir. 1956'da çıkarılan 6785 sayılı İmar Kanunu'nun, 20.07.1972 tarih ve 1605 sayılı yasa ile değiştirilen 28. maddesine göre, planlamaya esas alınan nüfus için kişi başına düşen yeşil alan miktarı en $7 \mathrm{~m}^{2}$ olarak belirlenmiştir. 1985 yılında çıkarılan ve halen yürürlükte olan 3194 sayılı İmar Kanunu'nda da bu standart korunmuştur. En son olarak 2 Eylül 1999'da çıkarılan bir yönetmelikle, kentsel ortamlarda kişi başına sağlanması gereken aktif yeşil alan miktarı 10 m²'ye çıkarılmıştır (Resmi Gazete, 1999).

Bu bağlamda incelenen çalışma alanlarında kişi başına düşen kentsel yeşil alan miktarının mevcut İmar Mevzuatı kapsaminda belirlenen asgari $10 \mathrm{~m}^{2}$ ve üzerinde olan sadece bir mahalle vardır. Tablo 2'de görüldüğü gibi Deniz Müzesi’nin bulunduğu Mahallesi'nde kişi başına düşen aktif yeşil alan miktarı $15.080 \mathrm{~m}^{2}$ ile yüksek
Şekil: 9

Rahmi M. Kof̧ Müzesi yakın çeure analizi. şekil: 10 Ara Güler Müzesi yakın çevre analizi.
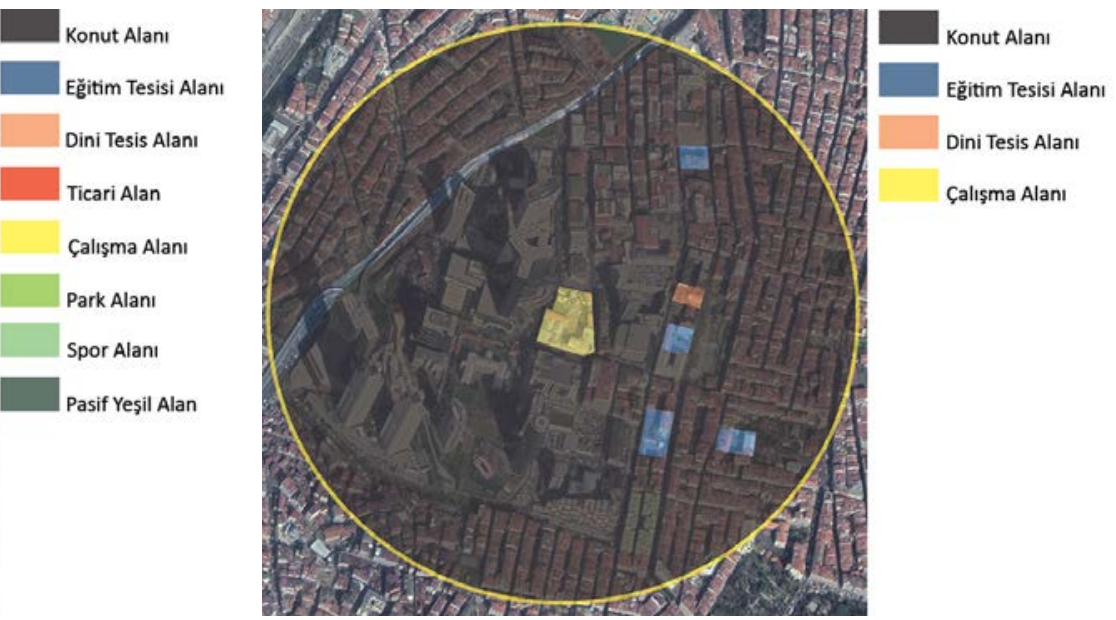
Şekil: II

Deniz Müzesi yakın f̧eure analizi.

Tablo: 2

çalışma a lanları yakın çeure açık alan analizi.

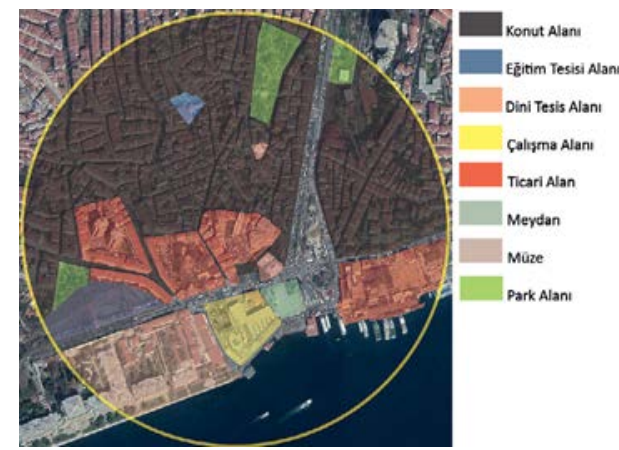

görünmektedir. Etkileşim alanı içerisinde pasif yeşil alan bulunmamaktadır. Beşiktaş ilçesinde bulunan Sinanpaşa Mahallesi nüfusunun az sayıda olması sebebiyle diğer alt bölgeler olan Piripaşa ve Örnektepe mahallelerinden daha az miktarda aktif yeşil alana sahip olsa da asgari sınırı aşmaktadır. İkinci en yüksek değere sahip bölge Miniatürk'ün bulunduğu Örnektepe Mahallesi'dir. Örnektepe Mahallesi'nde kişi başına düşen toplam yeşil alan miktarı $11.994 \mathrm{~m}^{2}$ iken, kişi başına düşen aktif yeşil alan miktarı $9.416 \mathrm{~m}^{2}$ görünmektedir. Bu sonuçlar bölgenin yeşil alan bakımından zengin ve yeşil alanların çoğunluğunun düzenlenmiş olduğunu göstermektedir. Kişi başına düşen pasif yeşil alan miktarı $2.578 \mathrm{~m}^{2}$ 'dir. $27.216 \mathrm{~m}^{2}$ 'lik bir alana sahip olan pasif yeşil alanlar ağaçlandırılmış eğimli araziden oluşmaktadır. Rahmi Koç Müzesinin bulunduğu Piripaşa Mahallesi'nde kişi başına düşen toplam yeşil alan miktarı $5.262 \mathrm{~m}^{2}$ iken kişi başına düşen aktif yeşil alan miktarı $3.917 \mathrm{~m}^{2}$ 'dir. Bölgenin kişi başına düşen pasif yeşil alan miktarı $1.345 \mathrm{~m}^{2}$ dir. Alt çalışma bölgeleri arasında en fazla toplam yeşil alan miktarına sahip olmasına rağmen en düşük aktif yeşil alan miktarına sahip Panorama 1453 Müzesi'nin olduğu Merkez Efendi
Mahallesi'nde kişi başına düşen yeşil alan miktarı $5.940 \mathrm{~m}^{2}$ iken aktif yeşil alan miktar1 $1.358 \mathrm{~m}^{2}$ 'dir. Bölgede toplamda $141.035 \mathrm{~m}^{2}$ 'lik bir alanı kaplayan yeşil alanların $32.245 \mathrm{~m}^{2}$ 'sini aktif yeşil alanlar oluşturmaktadır. Bu durum bölgenin yeşil alan bakımından oldukça zengin, tasarıma tabi tutulmuş yeşil alanlar açısından oldukça yetersiz olduğunu göstermektedir. Son alt bölge olan Ara Güler Müzesi'nin bulunduğu Şişli'deki Merkez Mahallesi'nde müzenin etkileşim alanına giren bölgede kamu kullanımına açık herhangi bir aktif yeşil alan bulunmamaktadır. 13.654 kişilik bir nüfusa sahip bölgede kentsel açık alan olarak sadece sokaklar bulunmaktadır. Bitişik nizamda, yoğun bir konut dokusuna sahip alanda farklı bir tipoloji olarak kendi yeşil alanlarına sahip olan kapalı siteler bulunmaktadır. Kamusal kullanım anlamında kentsel açıklık olarak meydan veya aktif yeşil alan kullanımlarına sahip olmadığ için Tablo 2'de değerlendirmeye alınmamıştır. Bu değerler Türkiye kentlerindeki yeşil alan değerlerini düzenleyen İmar Kanunu'nun getirdiği standartların altında kalmaktadır. Ayrıca çalışma alanındaki aktif yeşil alanlar mahalle ölçeğinde de homojen dağılmamaktadır.

Kentlerde kamusal açık alanların dağıllmını daha adil kılmak ve kentsel yaşamın daha sağlıklı bir şekilde sürdürülmesi kapsamında çalışma alanlarında alternatif kentsel açık alan üretimine katkı sağlamak amacıyla kamusal politika aracı olarak müzelerin açık alanları aktif yeşil alanlar olarak ele alınmıştır. Bu bağlamda incelenen çalışma alanlarında kişi başına düşen kentsel yeşil alan miktarının, mevcut İmar Kanunu'nda belirtilen asgari $10 \mathrm{~m}^{2}$ ve üzerinde olan sadece iki mahalle olduğu

\begin{tabular}{|l|l|r|r|r|r|r|r|r|}
\hline \multicolumn{1}{|c|}{ Müze } & Mahalle Adı & Nüfus & $\begin{array}{c}\text { Aktif Yeşil } \\
\text { Alan }\left(\mathrm{m}^{2}\right)\end{array}$ & $\begin{array}{l}\text { KBD Aktif } \\
\text { Yeşil Alan } \\
\left(\mathrm{m}^{2} / \mathrm{kişi}\right)\end{array}$ & $\begin{array}{r}\text { Pasif Yeşil } \\
\text { Alan }\left(\mathrm{m}^{2}\right)\end{array}$ & $\begin{array}{l}\text { KBD Pasif } \\
\text { Yeşil Alan } \\
\left(\mathrm{m}^{2} / \mathrm{kişi}\right)\end{array}$ & $\begin{array}{c}\text { Toplam } \\
\text { Yeşil Alan } \\
\left(\mathrm{m}^{2}\right)\end{array}$ & $\begin{array}{r}\text { KBD Yeşil } \\
\text { Alan } \\
\left(\mathrm{m}^{2} / \mathrm{kişi}\right)\end{array}$ \\
\hline Deniz M. & Sinanpaşa & 2.534 & 38.214 & 15,08 & - & - & 38.214 & 15.080 \\
\hline Miniatürk & Örnektepe & 10.556 & 99.397 & 9,416 & 27.216 & 2.578 & 126.613 & 11.994 \\
\hline Rahmi Koç M. & Piripaşa & 15.706 & 61524 & 3,917 & 21.135 & 1.345 & 82.659 & 5.262 \\
\hline Panorama 1453 M. & Merkez Efendi & 23.742 & 32.245 & 1,358 & 108.790 & 4.582 & 141.035 & 5.940 \\
\hline Ara Güler M. & Merkez & 13654 & - & & - & & & \\
\hline
\end{tabular}




\begin{tabular}{|c|c|c|c|c|c|c|c|c|}
\hline Müze & Mahalle Adı & Nüfus & $\begin{array}{l}\text { Aktif Yeşil } \\
\text { Alan }\left(\mathrm{m}^{2}\right)\end{array}$ & $\begin{array}{l}\text { KBD Aktif } \\
\text { Yeşil Alan } \\
\left(\mathrm{m}^{2} / \text { kişi) }\right.\end{array}$ & $\begin{array}{l}\text { Pasif Yeşil } \\
\text { Alan }\left(\mathrm{m}^{2}\right)\end{array}$ & $\begin{array}{l}\text { KBD Pasif } \\
\text { Yeşil Alan } \\
\left(\mathrm{m}^{2} / \text { kişi) }\right.\end{array}$ & $\begin{array}{c}\text { Toplam } \\
\text { Yeşil Alan } \\
\left(\mathrm{m}^{2}\right)\end{array}$ & $\begin{array}{c}\text { KBD Yeşil } \\
\text { Alan } \\
\left(\mathrm{m}^{2} / \text { kişi) }\right.\end{array}$ \\
\hline Deniz M. & Sinanpaşa & 2.534 & 40294 & 15,901 & - & - & 40.294 & 15.901 \\
\hline Miniatürk & Örnektepe & 10.556 & 137287 & 13,005 & 27.216 & 2.578 & 164.503 & 15.583 \\
\hline Rahmi Koç M. & Piripaşa & 15.706 & 75740 & 4,822 & 21.135 & 1.345 & 96.875 & 6.168 \\
\hline Panorama $1453 \mathrm{M}$. & Merkez Efendi & 23.742 & 52485 & 2,21 & 108.790 & 4.582 & 161.275 & 6.792 \\
\hline
\end{tabular}

görülmektedir. Tablo 3'de görüldüğü gibi müzelerin açık alanlarının kamusal kullanımının sağlanmasıyla Miniatürk Müzesi’nin bulunduğu Örnektepe Mahallesi'nde kişi başına düşen aktif yeşil alan miktarı 13.005 $\mathrm{m}^{2}$ 'ye çıkmaktadır. Kişi başına düşen toplam yeşil alan miktarı $6.792 \mathrm{~m}^{2}$ 'dir. Mevcut durumda kişi başına düşen asgari yeşil alan miktarını karşılayabilen, Deniz Müzesi'nin bulunduğu Sinanpaşa Mahallesi'nde müzenin açık alanlarının da analize eklenmesiyle kişi başına düşen aktif yeşil alan miktarı $15.901 \mathrm{~m}^{2}$ olmaktadır. 20.240 $\mathrm{m}^{2}$ açık alana sahip Panorama 1453 Müzesi kamusal politika kapsamında kentsel açık alan olarak ele alınmasına rağmen bölgede bulunan aktif yeşil alanların azlığı ve nüfus yoğunluğunun fazla olmasından dolayı asgari sınırı aşamamıştır. Merkez Efendi Mahallesi'nde kişi başına düşen aktif yeşil alan miktarı $2.210 \mathrm{~m}^{2}$ ye yükselmiştir ancak hala bölgedeki nüfus için yetersizdir. Bölgede kişi başına düşen toplam yeşil alan miktarı $6.792 \mathrm{~m}^{2}$ 'ye yükselmiştir. Rahmi Koç Müzesi'nin açık alanlarının analizde değerlendirilmesiyle Piripaşa Mahallesi'nde kişi başına düşen aktif yeşil alan miktarı $4.882 \mathrm{~m}^{2}$ 'ye yükselmektedir. Asgari sınırı aşamayan bölgede kişi başına düşen toplam yeşil alan miktarı 6.168 $\mathrm{m}^{2}$ 'dir. Ara Güler Müzesi'nin bulunduğu Şişli'deki Merkez Mahallesi'nde herhangi bir aktif yeşil alan, pasif yeşil alan ve kentsel açık alan bulunmamasına rağmen Ara Güler Müzesi 1950 m²'lik bir açık alana sahiptir.

Bu bağlamda İstanbul'daki müze bahçelerinin, kapsamlı ve planlı şekilde ele alınarak alternatif kentsel açık alanlar olarak değerlendirilmesi, bu konudaki ihtiyacı karşılamaya yönelik önemli bir potansiyel olarak görülmektedir. Müzelerin açık alanlarının alternatif açık alan olarak kullanılmasıyla yönetmelikte belirtilen en az $10 \mathrm{~m}^{2}$ lik aktif yeşil alan kriterine pozitif yönde katkı sağlayabilen bir kamu politikası oluşturulabilir. Müzelerin koruma politikalarına zarar vermeden açık alanları kentsel yaşama dahil edilebilir.

\subsection{Anket Çalışmasından Elde Edilen Bulgular}

Müzelerin açık alanlarının alternatif kentsel alan olarak kullanımının çalışma alanında yarattığı mekânsal ve sosyal etkileri saptamak, oluşumun kamusal politika aracı olarak gerçekleşme durumlarını belirlemek ve kentsel yaşama olan etkilerini ortaya çıarmak amacıyla anket çalışması yapılmıştır. Anket 53'ü kadın 38'i erkek olmak üzere 91 kişiye uygulanmıştır. Ankete katılanlardan 24'ü (\%26) 0-25 yaş aras1, 39'u (\%43) 26-45 yaş arası, 18'i (\%20) 46-65 yaş aras1, 10’u (\%11) 66 ve üstü yaş aralığındadır (Sekil 12).

Katılımcıların eğitim durumları incelendiğinde hala öğrenci durumunda olan 8

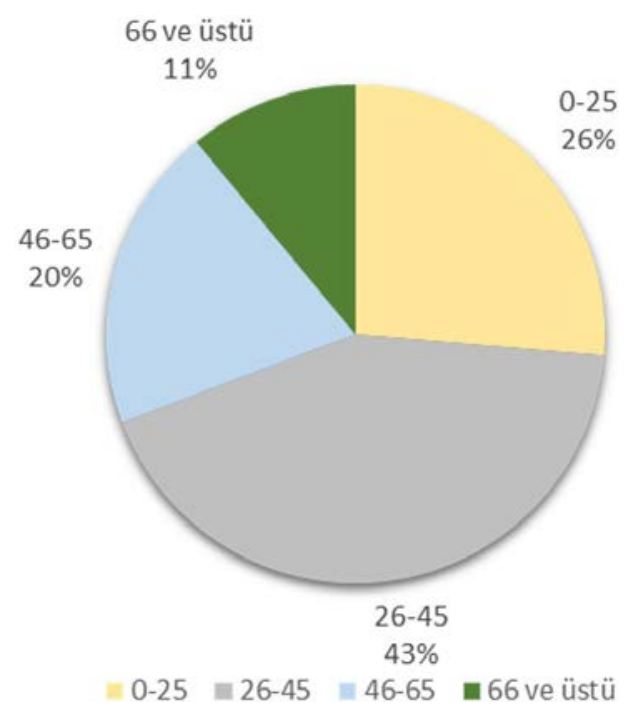

Tablo: 3

Alternatif açık alanların dahil edildiği yakın seure açık alan analizi.
Şekil: 12

Anket katılımcılarının yaş dağılımı. 
Şekil: 13

Anket katılımcılarının ě̆itim durumu.

Şekil: 14

Anket katılımcılarının açık alan ihtiyacı.

Şekil: is

Anket katılımcılarının serbest zaman mekân tercihleri.

şekil: 16

Günümüz müzelerinin açık alanlarının

kullanıma uygunluk durumu.
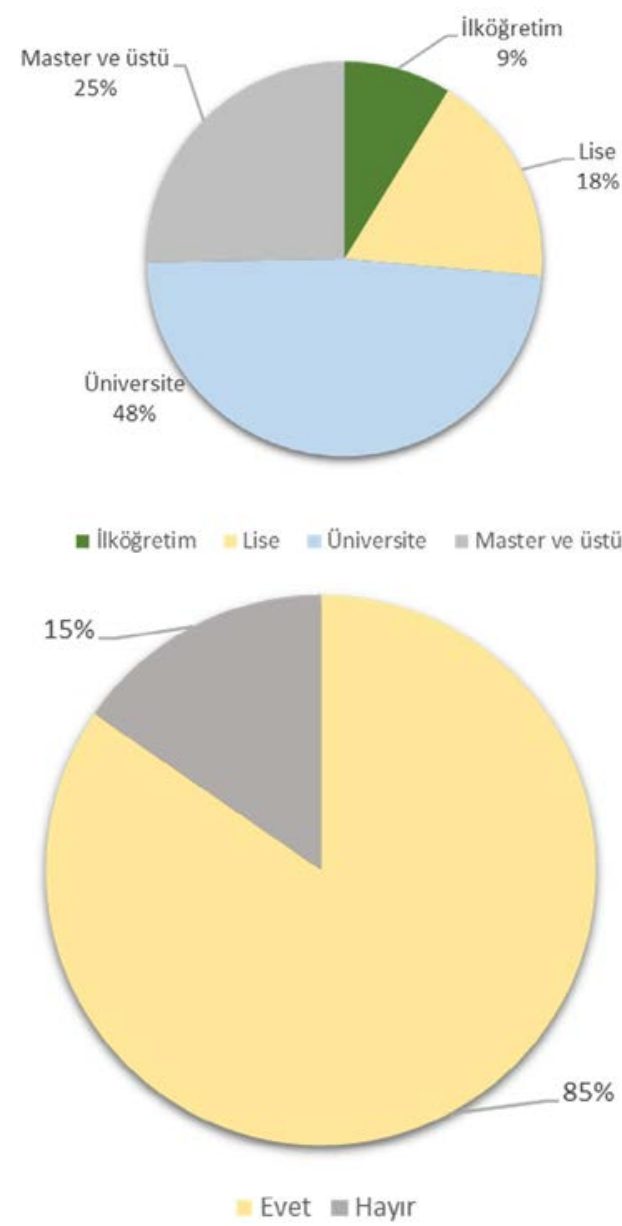

kişinin (\%9) ilköğretim seviyesinde, 16 kişinin (\%18) lise, 44 kişinin (\%48) üniversite ve 25 kişinin de (\%25) yüksek lisans ve üstü seviyede eğitime sahip oldukları görülmektedir (Sekil 13).

İstanbul'da kentlilerin kentsel açık alan ihtiyacının anlaşılabilmesi için 'İstanbul içerisinde serbest zamanlarınızı geçirebilecek açık alan ihtiyacı yaşıyor musunuz?' sorusu sorulmuştur. 77 kişi (\%85) kentsel açık alan ihtiyacı yaşadığını belirtirken, 14 kişi (\%15) kentsel açık alan ihtiyacı yaşamadığını belirtmiştir (Şekil 14).

Kentlilerin hangi tür kentsel açık alanları kullandıklarını anlamak amacıyla sorulan 'Serbest zamanlarınızda nerelerde vakit geçiriyorsunuz?' sorusuna 47 kişi (\%52) sahil kenarı, 11 kişi (\%12) AVM, 10 kişi (\%11) park, 10 kişi (\%11) cafe-restaurant, 7 kişi $(\% 8)$ sokak, 5 kişi (\%5) yer fark etmez cevabı verirken 1 kişi (\%1) sahil kasabası şeklinde cevaplamıştır. Çoğunluğun açık

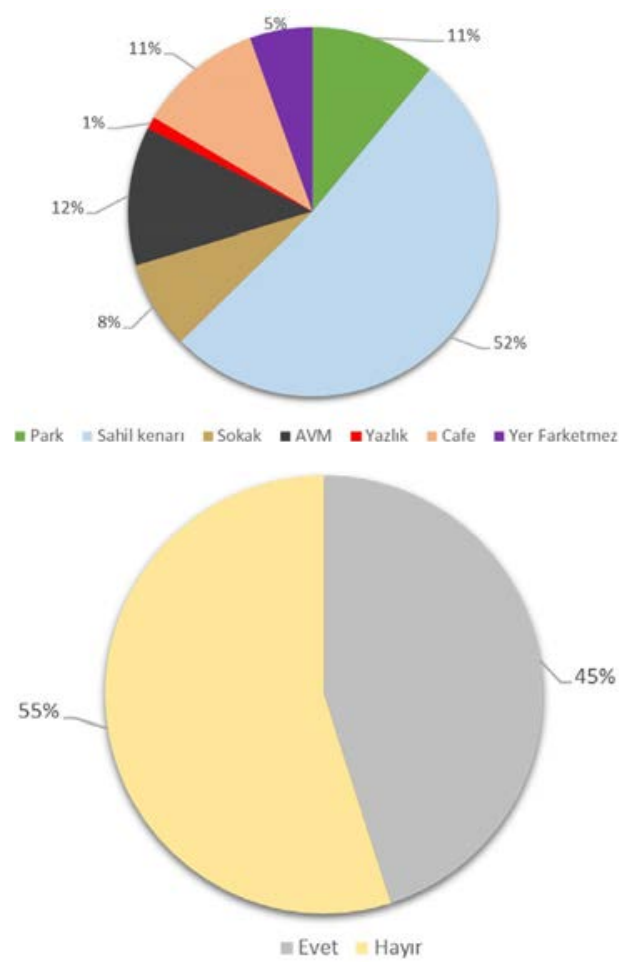

alanları tercih ettiği görülmektedir (Şekil 15).

Alternatif kentsel açık alan politikasının uygulama yeri olan müzelerin günümüz özelliklerinin serbest zaman kullanımı için uygun olup olmadığını test etmek amacıyla sorulan 'Müze açık alanlarının tasarımı boş zamanlarınızı geçirmek için uygun mu?' sorusunu 41 kişi (\%45) evet, 50 kişi (\%55) konfor yetersizliğinden dolayı hayır diyerek cevaplamıştır (Şekil 16).

Alternatif kamusal alan oluşturma politikasının sonuçlarının hedef grubu tarafından desteklenip desteklenmeyeceğini analiz etmek için sorulan 'Müzelerin açık alanlarının kamusal olarak kullanılması durumunda bu mekânları serbest zamanlarınızda kullanır mıdınız?' sorusunu 68 kişi (\%75) evet derken 23 kişi (\%25) hayır olarak cevaplamıştır (SSekil 17). Katılımcılar 'Müzelerin açık alanlarının kamusal olarak kullanılması durumunda beklentileriniz neler olur?' sorusuna genel anlamda kentin sosyal yaşamına destek verecek nitelikte cevaplar vermişlerdir. Müzelerin kent yaşamılla iç içe olmasını beklerken müzelerin koruma amaçlarının da zarar görmeyeceği şekilde gerekli güvenlik ve kontrol sistemine ihtiyaç olduğunu belirtmişlerdir. 


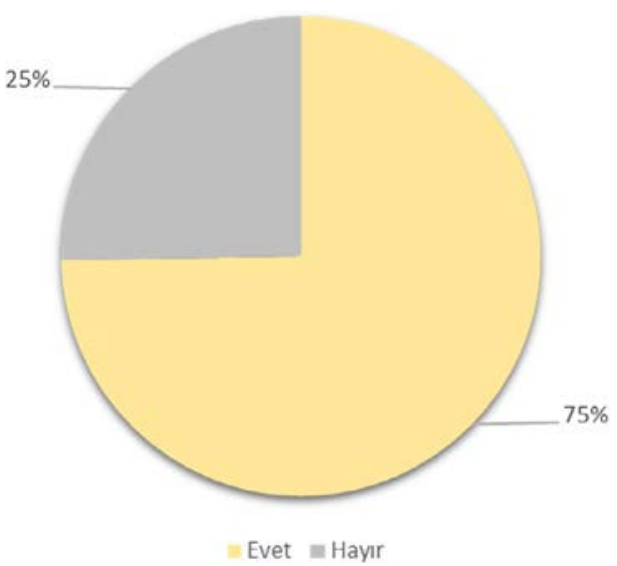

İstanbul'da kentsel açık alan ihtiyacı duyan katılımcıların çoğu müze açık alanlarının sosyal aktivite anlamında zengin bir içeriğe sahip olmasını beklemektedirler. Kolay erişilebilir, serbest zamanlarında bireysel ya da grup aktiviteleriyle zaman geçirebilecekleri temiz, konforlu ve güvenilir mekânlar haline getirilerek değerlendirilmesini istediklerini belirtmişlerdir. Kullanılmayan büyük kentsel boşluklar olarak kalmasının aksine açık alan kullanımlarını artıracak sergileme alanları, oturma alanları, alanın dokusunu bozmayacak şekilde mekâna destek verecek küçük ticari birimlerin ve mekânın korunan bitki örtüsü çeşitliliği ile kente dahil edilmesi yönündki fikirlerini belirtmişlerdir. Kentin içerisinde kentsel yaşamdan kaçmak için potansiyel olarak görülen bu mekânları destekleyenler dışında 10 kişi müzelerin zarar görme ihtimalinden dolayı mekânların bulundukları şekliye kalması gerektiğini belirtmiştir.

Kamu politikasının sonucunda elde edilecek olan alternatif açık alanların nasıl işlevlendirilmesi gerektiğinin tespitine

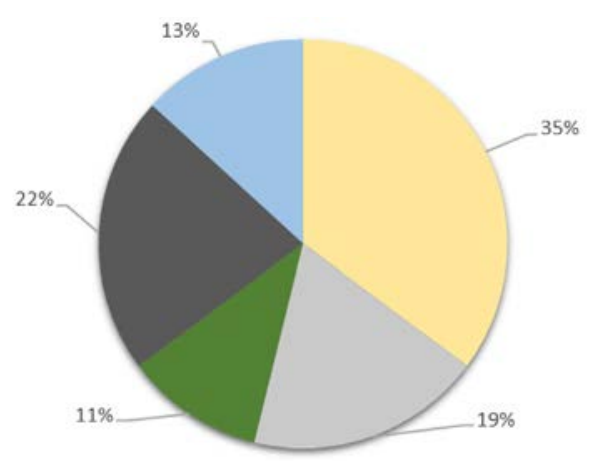

Serbest zaman geçirme = Aktvite amaçlı @ Bulușma amaçlı @ Öğrenme amaçlı = Hepsi Sayı 31, Kasım 2020 yönelik sorulan 'Müzelerin açık alanlarını ziyaret etme amacinız ne olurdu?' sorusuna katılımcılardan 32 kişi (\%35) serbest zaman amaçl1, 20 kiși (\%22) öğrenme amaçlı, 17 kişi (\%19) aktivite amaçl1, 10 kişi (\%11) buluşma amaçlı ve 12 kişi (\%13) seçeneklerden hepsi demiştir (Şekil 18).

Kamusal politika ve mekân oluşturma sürecinde katılım önemli bir faktördür. Müzelerin açık alanlarının alternatif kentsel açık alan olarak kullanımında sürece kullanıcıların katılıp katılmayacağını anlamak için sorulan 'Alternatif açık alan oluşturma etkinliklerine katılım gösterir misiniz?' sorusunu katılımcılardan 57 kiși (\%63) evet, 14 kiși (\%15) hayır ve 20 kiși (\%22) karars1zım şeklinde cevaplamıştır (Şekil 19).

Müze açık alanlarının alternatif kamusal alan olarak kullanımının etkilerini öğrenmek amacıyla katılımcılara 'Müze açık alanlarının kamusal olarak kullanılmasının sizi ve İstanbul'u nasıl etkileyeceğini anlatır mısınız?' sorusu sorulmuştur. Kentli bazında analiz edildiğinde kentsel yaşamlarında olumlu bir gelişme olabileceğini belirtmişlerdir.

Açık alanlara erişimin adil olmadığı İstanbul'da kentlilere alternatif mekânlar sunulması kentsel yaşamda sosyal hayatı zenginleştirecek ve artan karşılaşma mekânlarıyla kentsel iletişim güçlenecektir. Kentlilerin bir araya gelebileceği bu yeni mekânlarda kamu bilinci önem kazanacaktır. Günümüzde müze kavramı kentliler tarafından belli bir kesime hitap eden mekânlar olarak algılanırken açık alanlarının alternatif mekânlar olarak kullanılmasıyla en basit haliyle kentsel kaynaklara adil erişim olarak tanımlanan kent hakkında iyileşme görüle-

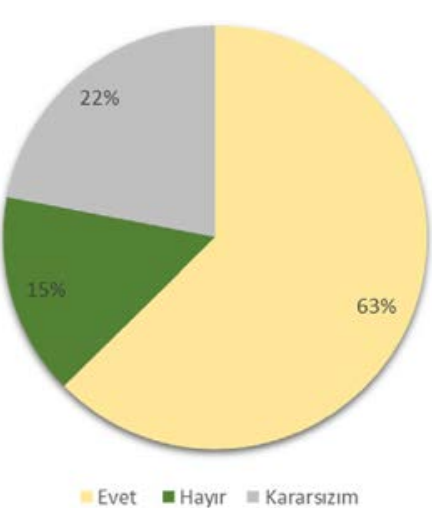

Şekil: 17

Anket katılımcılarının alternatif açık alanları kullanma tercihleri.
Şekil: 18

Anket katılımcılarının alternatif açık alanları kullanma amaçları.

Şekil: 19

Anket katılımcılarının mekân oluşturma etkinliklerine katılım durumu. 
cektir. Kent hakkı, kentsel kaynaklara adil erişim tanımını da aşarak, günümüzde kenti değiştirmek amacıyla kendimizi değiştirme / kendi geleceğimizi belirleme olarak sekillenmiștir. Kentlilerin kamusal alan ihtiyacı için alternatif mekân kullanımlarını desteklemeleri sosyal ve fiziksel anlamda kentsel politikaları da şekillendirecektir.

Ankete verilen cevaplar, müze bahçelerinin alternatif açık alanlar olarak değerlendirilmesi halinde kentsel yaşamın daha sağlıklı bir şekilde sürdürülebileceğini göstermektedir. Kentsel açık alan ihtiyacına yönelik alternatif çözüm yöntemleri sunmak kentin ekolojik yapısını iyileştirecektir. Farklı grupların bir araya geldiği yeni mekânların

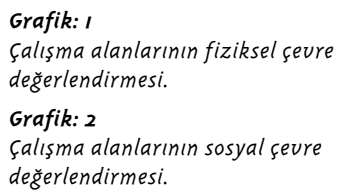

oluşmasıyla toplumsal farkındalık artacaktır. Alternatif açık alanların kazanılmasıyla, serbest zaman kullanım mekânları olarak sahil kenarı ve park gibi aktif yeșil alanlardaki kullanıcı yoğunluğu azalacaktır. Kentin sanat, kültür ve tarihle daha güçlü bir ilișkisi olacaktır. Müzeler kentlerde sadece sembolik bir anlam taşımakla kalmayacak, yaşayan ve yaşanılan mekânlara dönüşecektir. İstanbul'un kıyılarında bulunan birçok müze bahçesinin kamusal kullanıma açık olamaması, kamunun kıyı ile kurduğu bağı koparmaktadır. Müzelerin açık alanlarının alternatif kentsel açık alanlara dönüșmesiyle İstanbul kıyılarına erişimde süreklilik sağlanacak, kamunun kıyıyla kurduğu ilişki güçlenecektir.

Anketin ikinci bölümünde katılımcılardan, çalışma alanındaki müzeleri, literatürden elde edilen kriterler ışı̆̆ında değerlendirmeleri istenilmiştir (Grafik 1). Fiziksel çevre bazında değerlendirildiğinde Rahmi M. Koç Müzesi alternatif açık alan oluşturmada fiziksel kriterler açısından en uygun bulunan müze olarak öne çıkmaktadır. Deniz Müzesi ve Ara Güler Müzesi ikinci ve üçüncü sıradaki müzelerdir. Son iki sırada sirasiyla Miniatürk ve Panorama 1453 Müzesi bulunmaktadır. Rahmi M. Koç Müzesi’nin sahip olduğu fiziksel kullanım çeşitliliği, Deniz Müzesi'nin çevre fonksiyonlarının kentsel açık alanlardan oluşması ve Ara Güler Müzesinin bulunduğu avluya fiziksel olarak yansıyan komşuluk ilişkileri bu üç müzenin de fiziksel anlamda ortalamanın üzerinde bulunmasını sağlamıştır.

Sosyal çevre bazında değerlendirildiğinde Deniz Müzesi ve Ara Güler Müzesi sırasıyla en yüksek ortalamaya sahip müzelerdir (Grafik 2). Son üç sırada sırasıyla Rahmi M. Koç Müzesi, Panorama 1453 Müzesi ve Miniatürk bulunmaktadır. Yoğun bir kullanıcı çeșitliliği bulunan Deniz Müzesinin konum olarak cazibe noktasında bulunması ve bulunduğu bölgeyi etrafındaki komşu ünitelerle besleyen tek açık alan olan Ara Güler Müzesi sosyal anlamda yüksek bulunmuștur.

Çevresel algı bakımından değerlendirildiğinde Deniz Müzesi ve Rahmi M. Koç Müzesi en yüksek ilk iki ortalamaya sahip 
müzelerdir (Grafik 3). Ardından Ara Güler Müzesi, Panorama 1453 Müzesi ve Miniatürk gelmektedir. Endüstri mirası yapılı çevrenin müzeye dönüșümüyle oluşan Rahmi M. Koç Müzesi'nin toplumsal bellekte yer etmesi çevresel algı anlamında yüksek bulunmasını sağlamıştır.

Çalışma bölgelerinin kendi içlerine ortalamaları değerlendirildiğinde en yüksek ortalamaya sahip ilk üç müze Deniz Müzesi, Rahmi M. Koç Müzesi ve Ara Güler Müzesi'dir. Sonrakiler Panorama 1453 Müzesi ve Miniatürk şeklindedir. Özellikle Ara Güler Müzesi'nin bulunduğu bölgede tek açık alan olması, avlunun komşuluk ilişkilerine bağlı bir şekilde sürekli olarak kullanılmasıyla bölge için önemli bir alternatif açık alan olacaktır. Deniz Müzesi'nin yakın çevresinde bulunan kent meydanı ve kendi açık alanıyla bütüncül bir şekilde ele alınması Beșiktaş bölgesinde kıyı kullanımını güçlendirecektir. Haliç boyunca yer alan rekreasyon alanlarının kesintisiz bir şekilde devam edebilmesi, bölgedeki Miniatürk ve Rahmi M. Koç Müzesi gibi alternatif alanlarla oluşabilir. Son olarak Panorama 1453 Müzesi'nin bulunduğu çeper bölgesinde etrafındaki pasif ve aktif yeşil alanlarla bütüncül bir şekilde ele alınması, bölgedeki yeșil alan yoğunluğunun anlamlı bir şekilde kullanımını sağlayabilir. İstanbul'un farklı bölgelerinden alınan bu örnekleri bölgesel anlamda farklı özelliklere hizmet etse de kent bazında bakıldığında alternatif açık alan oluşumu kamu yararını ön plana çıkaran ve sağlıklı bir kentsel yaşamı ortaya çıkaran bir süreçtir.

\section{Sonuç}

Toplumun tüm gruplarına açık, ortak kullanım ve iletişim alanı olan kentsel açık alanlar, kentsel yaşamda çoklu işlevler üstlenen önemli ögelerdir. İçinde bulunduğu kentin sosyal ve ekonomik yapısını yansitan, kentsel kimliğin önemli sembollerinden olan alanlar kentleşme süreci içerisinde kentlerin yaşadığı dönüşümlerden etkilenmiştir. Endüstri sonrası dönemde, küreselleşme ve neoliberal kentleşme, kamusal mekânların nitel ve nicel yapıları ile işlevleri üzerinde önemli değişikliklere neden olmuştur. Tüketim kavramının kent- sel mekânlara yansımasıyla özelleştirilmiş, ticarileștirilmiş, metalaștırılmıs, kamunun tamamının erişemediği ve kontrol altında tutulan kamusal mekânlar oluşmuştur. Endüstri sonrası sermaye odaklı tasarım ve yönetim politikaları, kamusal alanların fiziksel, sosyal ve toplumsal anlamda zayıflamasına yol açarken, ticari roller yükleyerek de tüketim mekanlarına dönüştürmüştür.

Kentliler açık alan ihtiyacını günümüzde alternatif tasarım yöntemleriyle çözmektedir. Teraslar, çıkmaz sokaklar, üst geçitler, halka açık araziler ve binalar, ada içi boşluklar, iç avlular ile kullanım dışı bırakılmış istasyonlar ve duraklar alternatif açık alan potansiyeline sahip mekânlardır. Egemen politikalara karşı koyan ve onları dönüştürmeye yönelik olan kentsel ihtiyaca cevap verme amaciyla şekillenen ve dezavantajlı grupların yararına çalışan alternatif kentsel açık alanlar, sermaye odaklı kamu politikalarına karşı eylem alanlarıdır. Çalışma kapsamında da kentsel yaşamı doğrudan ve dolaylı olarak etkileyen müzelerin açık alanlarının alternatif açık alan olarak değerlendirilmesi dünya literatüründen örnekler ele alınarak incelendiğinde görülmektedir ki; müzeler kentlerde yalnızca kimlik ögesi oluşturmaya yönelik değil, yer oluşturma (placemaking), taktiksel şehircilik (tactical urbanism) ve uyarlanabilir yeniden kullanım (adaptive reuse) gibi tasarım uygulamalarıyla bulunduğu kentle ilişki

Grafik: 3

Çalışma alanlarının çeuresel algı değerlendirmesi.

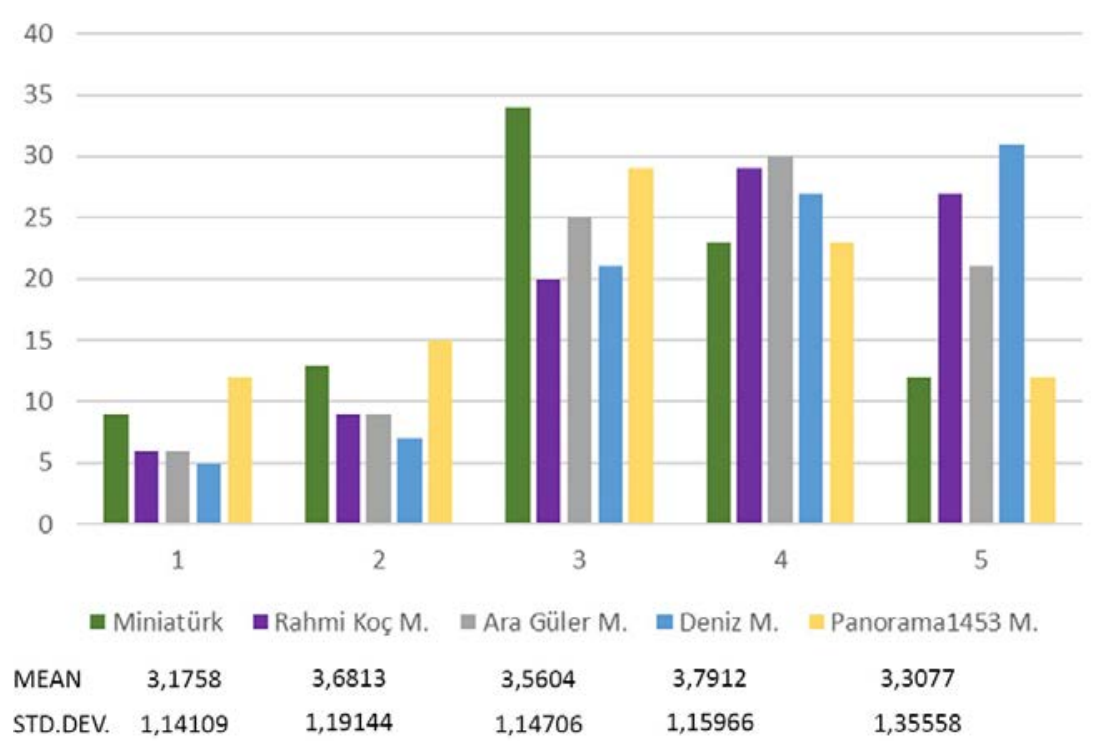


kuran ve yaşayan mekânlar olarak kentlilerin istek ve gereksinimlerini karşılayabilen mekânlardır. Bu bağlamda değerlendirilen müzelerin fiziksel çevre, sosyal çevre ve çevresel algı altında ortak kullanılabilirlik kriterleri bulunmaktadır. Fiziksel çevreye dair kriterler; müzelerin mekânsal özellikleri ile kullanım-aktivite çeşitliliğini kapsarken, sosyal çevre kriterleri müzelerin bulunduğu bölge ile kurduğu ilişki, kullanıcı profilleri ve sosyal yapısını kapsamaktadır. Çevresel algıya dair kriterleri ise, kentlilerin müzeye ve yakın çevresine dair izlenimleri oluşturmaktadır.

Çalışma kapsamında müze açık alanlarının alternatif açık alan olarak kullanım politikası, İstanbul'da kentsel açık alan erişilebilirliğine göre ele alınmıştır. İstanbul'un kentsel açık alan ihtiyacına çözüm olarak sunulan politika önerisinde amaç kentlerin, 3194 sayılı İmar Kanunu'nda belirtilen kişi başına düşen minimum aktif yeşil alan miktarına erişmesine katkı sağlamaktır. Yapılaşma baskısı ile kentsel açık alanlarında niceliksel bir azalma meydan gelirken müzelerin açık alanlarıyla bu soruna alternatif bir çözüm olușturulması hedeflenmiștir. Buna göre İstanbul'da müzelerin alternatif açık alanlar olarak değerlendirilmesiyle açık alanlara erişilebilirlikte pozitif yönlü bir gelişme gözlemleneceği öngörülmektedir. İmar Kanunu'nda açık alanlar için getirilen standartların sağlanamadığı günümüz koşullarında müzeler, açık alanları ve yakın çevreleriyle bütüncül bir şekilde ele alınarak tasarlandığında kentsel yaşamda ve kent dokusunda sağlıklı bir gelişme gözlemlenecektir. Müzelerin açık alanlarındaki konfor ve aktivite çeşitliliklerindeki eksikliklerden ötürü değerlendirilemeyen mekânlar, düzenlenmeleriyle birlikte kentte sıklıkla kullanılan parklar, rekreasyon alanları ve sahil kenarlarında kullanıcı yoğunluğunda adil bir dağılım gözlemlenebilir. Müze açık alanlarının konfor özelliğini artıracak tasarım uygulamaları ve sosyal yapısını zenginleștirecek uygun aktivite çeşitliliğgi ile kentlilerin bir araya gelebileceği yeni mekânların oluşmasıyla kamu bilinci kentte güçlenecektir. İstanbul'da müzelerde alternatif açık alan oluşturma politikası, kentliler ve sivil toplum kuru- luşları önderliğinde idari birimlerle ortak çalışılan, kentte kamusal mekân ve kentsel yaşam kalitesini iyileştirmeye yönelik, kent ile kentliler arasındaki ilişkiler ile müzeleri fiziksel anlamda kullanım, aktivite, erişim ve koruma alanlarında güçlendiren eylemlerden oluşan bir süreçtir. Alternatif açık alan oluşturma politikası, insanları küreselleşmenin dayattığı kapalı tüketim mekânlarına yönelmesini engelleyen bir uygulama ve kenti, rant aracı haline getirerek, kentlilerin karşılaşma, ilişki kurma alanını sınırlayan, katılımeı olmayan yollarla ortaya çıkan tüm uygulamalara karşı verilen bir kent hakkı mücadelesidir• 


\section{Kaynakça}

Artun, A. (2008). Müzecilikte Kamusallığın Kaynakları ve Özel Müzeler. http://www.aliartun.com/yazilar/ muzecilikte-kamusalligin-kaynaklari-ve-ozel-muzeler/

Barnett, J. (1974). Urban Design As Public Policy: Practical Methods for Improving Cities. New York: Architectural Record Books.

Broadhurst, R. (1989). The search for new funds. Uzzell, D. (Ed.), Heritage Interpretation: The visitor experience, 2. cilt içinde. Londra: Belhaven Press.

Byrne, D. (1991). Western hegemony in archaeological management. History and Archaeology. 5, 269-276.

Carmona, M. (2010). Contemporary Public Space, Part Two: Classification. Journal of Urban Design, 15(2).

Carr, S., Francis, M., Rivlin, L. G., Stone, A. M. (1992). Public Space. Cambridge: Cambridge University Press.

De Oliveira, N., Oxley, N., Petry, M. (2005). Installation Art in the New Millenium. Londra: Thames and Hudson Ltd.

Dye, T.R. (1987). Understanding Public Policy. Prentice Hall.

Fisker, J. K., Chiappini, L., Pugalis, L., Bruzzese, A. (2019). Conceptualising The Production of Alternative Urban Spaces. J.K. Fisker, L. Chiappini, L. Pugalis ve A. Bruzzese (Ed.), The Production of Alternative Urban Spaces içinde (s. 1-14). New York: Routledge.

Fisker, J. K., Chiappini, L. (2019). An International Dialogue on The Production of Alternative Urban Spaces. J. K. Fisker, L. Chiappini, L. Pugalis ve A. Bruzzese (Ed.), The Production of Alternative Urban Spaces içinde (s. 227-240). New York: Routledge.

Fraser, N. (1992). Rethinking The Public Sphere: A Contribution To The Critique Of Actually Existing Democracy. Cambridge: MIT Press.

Gehl, J., Svarre, B. (2013). How to Study Public Life. Washington DC: Island Press.

Gehl, J. (1996). Life Between Buldings Using Public Space. Washington DC: Island Press.

Goulding, C. (2000). The Museum Environment And The Visitor Experience. European Journal Of Marketing, 34 (3/4), 261-278.

Habermas, J. (2000). Kamusallı̆̆ın Yapısal Dönüsümü. (Çev.) T. Bora ve M. Mithat. İstanbul: İletişim Yayınları.

Jacobs, J. (1961). Büyük Amerikan Şehirlerinin Ölümü ve Yaşamı. (Çev.) B. Doğan. İstanbul: Metis Yayınları.

MacLeod, S., Austin, T., Hale, J., Hing-Kay, O. H. (2018). The Future of Museum and Gallery Design: Purpose, Process, Perception. Londra: Routledge.

Moughtin, C. (1999). Urban Design: Street and Square, 2nd Ed. Oxford: Architectural Press.

Negt, O., Kluge, A. (1991). Kamusal Alan ve Deneyim. (Çev.) A. Doğukan. Defter, 16, 65-76.

Özbek, M. (Ed.) (2004). Kamusal Alan. İstanbul: Hil Yayın.

Resmî Gazete (1999). 23804 Sayılı İmar Yönetmeliği. Ankara.

Sennett, R. (2013). Kamusal İnsanın Çöküsü. (Çev.) S. Durak ve A. Yılmaz. İstanbul: Ayrıntı Yayınları.

Şentürk, L. (2012). Analitik Resim Çözümlemeleri. İstanbul:
Ayrıntı Yayınları.

Tibbalds, F. (1992). Making People-Friendly Towns. Essex: Longman.

Trancik, R. (1986). Finding Lost Space: Theories of Urban Design. New York: John Wiley \& Sons.

Weimer, D. L., Vinning, A. R. (1998). Policy Analysis: Concepts and Practice, 3rd Ed. Prentice Hall.

Whyte, W. H. (1980). The Social Life of Small Urban Spaces. Conservation Foundation.

Nüfus verileri: http://tuik.gov.tr/PreTablo.do?alt_id=1059

URL-1 https://lesgrandsvoisins.org/ https://cigue.ch/logement/clos-voltaire-2/

URL-2 https://www.archdaily.com/876677/ the-peckham-observatory-cooke-fawcett https://www.designboom.com/art/craig-karl-gas-station-london-white-city-06-04-2017/

URL-3 https://weburbanist.com/2017/04/12/underpass-art-parks-15-fun-projects-reclaiming-disused-urban-space/3/ http://www.pariste.net/la-petite-ceinture/

URL-4 https://www.oestergro.dk/

http://spacing.ca/toronto/2012/05/23/ groundbreak-in-new-york-citys-artist-alley/ 